\title{
EXAMINING THE CRIMINAL REGIME IN CHAPTER 7 OF THE CORPORATIONS ACT
}

\author{
STEPHEN SPEIRS $*$
}

\begin{abstract}
The criminal regime in ch 7 of the Corporations Act 2001 (Cth) contains 299 separate offences and is extremely complex. This article undertakes the first detailed examination of the criminal regime in ch 7 in anticipation of an increase in criminal prosecutions of financial services misconduct following the Royal Commission into Misconduct in the Banking, Superannuation and Financial Services Industry. This examination uncovers a number of drafting anomalies and inconsistencies in the criminal regime. In the light of these issues, the article advocates simplification of the criminal regime and puts forward reform proposals aimed at fostering compliance and observance of the law.
\end{abstract}

\section{INTRODUCTION}

The criminal regime in ch 7 of the Corporations Act 2001 (Cth) ('Corporations Act') - the chapter primarily responsible for the regulation of financial services - is pervasive. It comprises 299 separate offences splintered across 991 pages. $^{1}$ Despite its reach, in the 10 year period leading up to the Royal Commission into Misconduct in the Banking, Superannuation and Financial Services Industry ('Royal Commission'), the Australian Securities and Investment Commission ('ASIC') secured only one criminal conviction against an Australian Financial Services Licensee ('AFSL') holder. ${ }^{2}$ As the criminal regime in ch 7 of the Corporations Act had been left largely unused, it remained largely unexamined.

Following the Royal Commission, however, the criminal regime in ch 7 appears set to finally bare its teeth. Responding to criticisms of its perceived failure to litigate serious corporate wrongdoing in the Royal Commission's Interim Report ${ }^{3}$ and Final Report, ${ }^{4}$ ASIC recalibrated its enforcement strategy by adopting a 'Why Not Litigate?' approach. ${ }^{5}$ This new enforcement strategy gives

\footnotetext{
Barrister, Sixth Floor Selborne/Wentworth Chambers, Sydney.

Corporations Act 2001 (Cth) ('Corporations Act'). The analysis in this article of the Corporations Act is based on Compilation No 98, registered on 22 April 2020.

Royal Commission into Misconduct in the Banking, Superannuation and Financial Services Industry (Interim Report, September 2018) vol 1, 276 [2.4] ('Interim Report').

Ibid, xix.

Royal Commission into Misconduct in the Banking, Superannuation and Financial Services Industry (Final Report, February 2019) vol 1 ('Final Report'), 433 [3.4].

Michael Legg and Stephen Speirs, "“Why Not Litigate?" - The Royal Commission, ASIC and the Future of the Enforcement Pyramid' (2019) 47(4) Australian Business Law Review 244.
} 
greater prominence to criminal enforcement. ASIC has stated publicly that it will refer matters to the Commonwealth Department of Public Prosecutions ('CDPP') whenever there is 'sufficient evidence to support the view that a criminal offence has been committed and that the circumstances of the matter warrant a criminal prosecution' ${ }^{6}$ an approach that ASIC has predicted would result in referrals to the CDPP increasing by a staggering 82 per cent in the two-year period following the Royal Commission. ${ }^{7}$ In other words, ASIC now appears set to leverage the criminal regime in ch 7 to sanction misconduct that, prior to the Royal Commission, it would likely have addressed through non-criminal enforcement options such as an administrative or civil penalty.

Results of this changed emphasis are already emerging. In the second half of 2019 alone, ASIC laid 279 charges, 'an almost fourfold increase' on the number of charges laid in the first half of 2019, and an even greater increase on the number of charges laid prior to the Royal Commission. ${ }^{8}$ With respect to financial services misconduct specifically, as at 1 January 2020, there were 16 active criminal matters before the courts waiting determination, and since the publication of the Royal Commission's Final Report in February 2019, ASIC has run three criminal cases against AFSL holders to a resolution, securing convictions in all three cases. ${ }^{9}$ Relevantly, each of these three prosecutions was brought against large financial services institutions and tested offence provisions in ch 7 that had never previously been enforced. However, with the onset of COVID-19, and changes to ASIC's leadership team in 2021, ${ }^{10}$ it remains to be seen whether this new reliance on the criminal law will become a permanent feature of ASIC's enforcement approach.

If ASIC needed further motivation, the passing of the Treasury Laws Amendment (Strengthening Corporate and Financial Sector Penalties) Bill 2018 (Cth) ('Strengthening Penalties Bill') - just 18 days after the Royal Commission's Final

6 Commissioner Sean Hughes, 'ASIC's Approach to Enforcement after the Royal Commission' (Speech, Banking and Financial Services Law Association, 30 August 2019).

7 Parliamentary Joint Committee on Corporations and Financial Services, Parliament of Australia, Oversight of the Australian Securities and Investments Commission (Transcript, 19 October 2018) 33 <https://parlinfo.aph.gov.au/parlInfo/search/display/display.w3p;query=Id:\%22committees/comm jnt/5a873144-a31e-466d-aeoe-338d6937b796/0001\%22>.

8 Joyce Moullakis, 'ASIC on Criminal Charging Spree as Hayne Criticism Bites', The Australian (online, 29 April 2020) <https://www.theaustralian.com.au/business/asic-on-criminal-charging -spree-as-hayne-criticism-bites/news-story/7af68522a5b339782d5788dc507df182>.

9 See, ASIC, 'CommInsure Sentenced for Hawking Offences' (Media Release 19-344MR, 28 November 2019); ASIC, 'Pershing Sentenced for Breaching Client Money Offences' (Media Release 20-178MR, 5 August 2020); ASIC, 'Societe Generale Securities Australia Pty Ltd Receives \$30,000 Penalty for Breaching Client Money Rules' (Media Release 20-252MR, 21 October 2020).

$10 \quad$ On 29 April 2021, Joseph Longo was appointed Chairman of ASIC, replacing James Shipton, and Sarah Court was appointed Deputy Chairperson, replacing Daniel Crennan QC. They were both appointed for a 5-year term, commencing on 1 June 2021. See, Treasury, 'Appointment of New Chairperson and Deputy Chairperson to the Australian Securities and Investments Commission' (Media Release, 29 April 2021). 
Report was handed down - has provided it. ${ }^{11}$ The Strengthening Penalties Bill dramatically increased the maximum penalties attaching to offence provisions in the Corporations Act. An individual defendant now faces a maximum prison term of 15 years, and a body corporate faces a maximum pecuniary penalty, the greater of: (1) $\$ 9,990,000$; (2) three times the value of the benefit derived or the detriment avoided by the contravention; or (3) 10 per cent of the annual turnover of the corporation for the 12 month period at the end of the month in which the company committed or began committing the offence..$^{12}$ ASIC, unsurprisingly, has embraced these reforms. Its former Chair, James Shipton, remarked that 'these new powers and penalties will be of greater deterrence value and will make a meaningful difference'. ${ }^{13}$

Against this background, it is appropriate to conduct a detailed review of the criminal regime - that is, the substantive criminal offences - contained in ch 7 of the Corporations Act. This article undertakes this review in Part II. What emerges is a very complex regime in urgent need of simplification. This complexity derives predominately from the way the regime has been drafted and is structured. Three major issues appear. First, as offence provisions have been inserted into ch 7 by amendment over time, they have not been drafted consistently. The review examines the different drafting formulae used by the legislature and their implications on enforcement. Secondly, in order to 'find' an offence provision in ch 7 (or to know that a provision constitutes an offence) it is necessary to understand how an offence provision interacts with provisions in other parts of the Corporations Act, especially pt 9.4 (which generally regulates 'offences') and sch 3 (which lists a large majority, but not all, of the criminal penalties that attach to the offence provisions in the Corporations Act). This article will provide guidance on how to navigate this complex network of provisions. Thirdly, issues arise from the interactions of the offence provisions in ch 7 with provisions in the Crimes Act 1914 (Cth) ('Crimes Act') and Criminal Code Act 1995

See, Treasury Laws Amendment (Strengthening Corporate and Financial Sector Penalties) Bill 2018 (Cth) ('Strengthening Penalties Bill'). Although the swiftness of this reform following the issuance of the Final Report of the Royal Commission is notable, it should be observed that the legislation actually implements a recommendation of the ASIC Enforcement Review Taskforce of 2017, which held that the penalty regime was inadequate to address the severity of misconduct, with penalties being 'too low' to act as a 'credible deterrent': see Department of Treasury and Finance (Cth), ASIC Enforcement Review Taskforce, ASIC Enforcement Review Taskforce Report, 18 December 2017, 71, 94-95 ('ASIC Taskforce Final Report').

12 Corporations Act (n 1) s 1311C(3). Previously, with limited exceptions, the maximum penalty for a body corporate was five times the maximum penalty that applied to an individual (see former s 1312 of the Corporations Act), with the maximum penalty for an individual being, immediately before the amendments, capped at $\$ 420,000$.

13 James Shipton, 'The Fairness Imperative' (Speech, AFR Banking and Wealth Summit, 27 March 2019) <https://asic.gov.au/about-asic/news-centre/speeches/the-fairness-imperative/>. 
(Cth) ('Criminal Code'), both of which contain matters of general application that apply to all federal offences, including those in the Corporations Act. ${ }^{14}$

Having identified these issues, Part III puts forward specific proposals for legislative reform aimed at simplifying the criminal regime in ch 7 . The objective driving these proposals is straightforward: to make clear when conduct regulated by ch 7 constitutes an offence and may attract criminal consequences. Although the proposals put forward are ambitious, in the post-Royal Commission world there is renewed appetite for reform. In September 2020, the Commonwealth Attorney-General asked the Australian Law Reform Commission ('ALRC') to conduct a review into the laws that regulate financial services in Australia, and to consider 'what changes to the Corporations Act 2001 ... could be made to simplify and rationalise the law' ${ }^{15}$ The ALRC is due to publish its final report by 30 November 2023. One may hope that the ALRC's inquiry will catalyse government action on the matters discussed in this article.

\section{The CRIMINAL Regime IN CHAPTER 7}

Chapter 7 contains 299 separate criminal offence provisions. ${ }^{16}$ Cataloguing these provisions is no simple task. As will be shown, the offence provisions are drafted

$14 \quad$ Note, the carving out of the corporate attribution model in pt 2.5 of the Criminal Code by s 769A of the Corporations Act falls outside the scope of this article. The corporate attribution model that applies to the offence provisions in ch 7 sits in s 769A and was recently examined by the Australian Law Reform Commission ('ALRC') as part of its review into Australia's corporate criminal responsibility regime. See generally, ALRC, Corporate Criminal Responsibility (Final Report No 136, April 2020) ('ALRC Final Report').

15 Christian Porter, Attorney-General, 'Terms of Reference', Australian Law Reform Commission: Review of the Legislative Framework for Corporations and Financial Services Regulation (Web Page, 11 September 2020) <https://www.alrc.gov.au/inquiry/review-of-the-legislative-framework-forcorporations-and-financial-services-regulation/terms-of-reference/ $>$.

16 See Corporations Act (n 1) ss 791A(1), 791B, 792B(1), 792B(2), 792B(3), 792B(4), 792B(5), 792C(1), 792D(1), 792E, 792F(1), 792F(2), 792F(3), 792G(1), 792G(2), 792I, 793D(3), 794B(3), 798C(3), 798C(6), 794D(3), 794E(2), 798D(4), 798DA(4), 820A(1), 820B, 821B(1), 821B(2), 821B(3), $821 \mathrm{~B}(4), 821 \mathrm{BA}(1), 821 \mathrm{C}(1), 821 \mathrm{C}(3), 821 \mathrm{D}, 821 \mathrm{E}(1), 821 \mathrm{E}(2), 821 \mathrm{E}(3), 822 \mathrm{D}(3), 823 \mathrm{~B}(3), 823 \mathrm{D}(5)$, $823 \mathrm{E}(3), 850 \mathrm{C}, 851 \mathrm{D}(8), 852 \mathrm{~B}(2), 853 \mathrm{~F}(1), 853 \mathrm{~F}(2), 854 \mathrm{~A}(4), 892 \mathrm{~B}(1), 892 \mathrm{~B}(3), 892 \mathrm{H}(1), 892 \mathrm{H}(2)$, $892 \mathrm{H}(3), 892 \mathrm{H}(6), 892 \mathrm{H}(7), 892 \mathrm{~K}(2), 904 \mathrm{~B}(1), 904 \mathrm{~B}(5), 904 \mathrm{C}(1), 904 \mathrm{C}(3), 904 \mathrm{D}(2), 904 \mathrm{E}$, $904 \mathrm{G}(5), 904 \mathrm{H}(3), 904 \mathrm{~K}(4), 905 \mathrm{~A}(2), 907 \mathrm{~A}, 911 \mathrm{~A}(1), 911 \mathrm{~B}(1), 911 \mathrm{C}, 912 \mathrm{C}(3), 912 \mathrm{D}(1 \mathrm{~B}), 912 \mathrm{D}(2)$, $912 \mathrm{E}(1), 912 \mathrm{~F}(1), 916 \mathrm{~A}(3 \mathrm{~A}), 916 \mathrm{~B}(2 \mathrm{~A}), 916 \mathrm{~B}(5 \mathrm{~A}), 916 \mathrm{C}(3), 916 \mathrm{D}(2 \mathrm{~A}), 916 \mathrm{~F}(1), 916 \mathrm{~F}(1 \mathrm{~A}), 916 \mathrm{~F}(3)$, 916G(2), $916 \mathrm{G}(3), 920 \mathrm{C}(3), 922 \mathrm{M}(3), 923 \mathrm{~A}(1), 923 \mathrm{~B}(1), 923 \mathrm{C}(1), 923 \mathrm{C}(2), 942 \mathrm{~B}(8), 942 \mathrm{C}(8), 942 \mathrm{E}$, $943 \mathrm{~F}, 946 \mathrm{AA}(4), 946 \mathrm{~B}(3 \mathrm{~A}), 946 \mathrm{~B}(9), 949 \mathrm{~A}(2), 949 \mathrm{~A}(5), 949 \mathrm{~B}(2), 949 \mathrm{~B}(4), 952 \mathrm{C}(1), 952 \mathrm{C}(3)$, 952D(1), 952D(2), 952E(6), 952F(2), 952F(3), 952F(4), 952 G(2), 952G(4), 952G(6), 952H(2), 952I(1), 952I(2), 952I(3), 952I(4), 952J(1), 952K, 952L(1), 952L(2), 952L(3), 952M, 982C(1), $982 \mathrm{C}(2), 982 \mathrm{D}, 983 \mathrm{C}, 984 \mathrm{~B}(1), 985 \mathrm{D}(1), 985 \mathrm{~J}(1), 985 \mathrm{~J}(2), 985 \mathrm{~J}(4), 985 \mathrm{~K}(1), 988 \mathrm{~A}(1), 989 \mathrm{~B}(1)$, 989B(2), 989B(3), 989CA(3), 989CA(4), 990B(1), 990B(2), 990B(6), 990D(1), 990D(2), 990F(a), 990I(3), 990K(1), 991B(2), 991E(1), 991E(3), 991F(1), 991F(2), 991F(3), 992A(1), 992A(3), 992AA(1), 993B(1), 993B(3), 993C(1), 993C(3), 993D(2), 993D(3), 1012DA(9), 1012DAA(10), $1012 \mathrm{H}(2), 1013 \mathrm{I}(4), 1013 \mathrm{IA}(5), 1013 \mathrm{~K}(1), 1013 \mathrm{~K}(2), 1015 \mathrm{~B}(1), 1015 \mathrm{D}(2), 1015 \mathrm{D}(3), 1015 \mathrm{D}(4), 1015 \mathrm{E}(1)$, 
in several different ways. Adding to the complexity of this task, it is also necessary to understand how these provisions interact with provisions elsewhere in the Corporations Act, as well as provisions in the Crimes Act and Criminal Code. ${ }^{17}$ To provide some order and coherence to the criminal regime in ch 7, this Part organises the offence provisions by reference to: (A) how the offences are drafted; (B) the 'type' of offences (ie, whether an offence provision contains 'fault elements' or is a continuing offence); and (C) the seriousness of the offences.

\section{A How Offences are Drafted in Chapter 7}

A fundamental distinction is drawn in ch 7 between 'specific' offences and 'general' offences. This terminology, referring to the offence provisions in ch 7 as 'general' or 'specific' offences, was coined by Bird and Gilligan. ${ }^{18}$ Broadly, the two terms denote how the offence provisions in ch 7 are drafted. That is, 'specific' offences are provisions in which an offence is specifically or expressly provided for in the provision itself..$^{19}$ This is to be contrasted with 'general' offence provisions, which are not offences per se (the provisions containing no express indicia of an offence), and which are only made offences by virtue of s 1311 (see, pt II(A)(e)(3)).

It is important to observe that the terms general and specific, as defined by Bird and Gilligan, apply only to offence provisions in the Corporations Act, and that the same terms hold different meanings when used elsewhere in the criminal law. Whereas the terms when used by Bird and Gilligan reflect the 'form' of the offence provision in ch 7, the same terms when used more generally in the criminal law depict the content or substance of an offence.

One way to understand the general criminal law meaning of the terms is by reference to the distinction between rule-based and principle-based offences. The former are highly prescriptive and specifically identify the precise conduct that is prohibited (hence, 'specific' offences), whereas the latter are drafted more

$1016 \mathrm{~A}(2), 1016 \mathrm{~A}(3), 1016 \mathrm{~B}(1), 1016 \mathrm{C}, 1016 \mathrm{D}(1), 1016 \mathrm{D}(2)(\mathrm{d}), 1016 \mathrm{E}(2), 1017 \mathrm{~B}(1), 1017 \mathrm{C}(2)$ $1017 \mathrm{C}(2 \mathrm{~A}), 1017 \mathrm{C}(3), 1017 \mathrm{C}(3 \mathrm{~A}), 1017 \mathrm{C}(5), 1017 \mathrm{D}(1), 1017 \mathrm{DA}(3), 1017 \mathrm{E}(3), 1017 \mathrm{E}(4), 1017 \mathrm{~F}(2)$, $1017 \mathrm{G}(1), 1018 \mathrm{~A}(1), 1018 \mathrm{~A}(2), 1018 \mathrm{~B}(1), 1020 \mathrm{~A}(4), 1020 \mathrm{AB}(3), 1020 \mathrm{AC}(2), 1020 \mathrm{AD}(2), 1020 \mathrm{AE}$, 1020AI(3), 1020AI(5), 1020AI(7), 1020AJ, 1020B(2), 1020BAA(1), 1020E(8), 1020E(9), 1021C(1), $1021 \mathrm{C}(3), 1021 \mathrm{D}(1), 1021 \mathrm{D}(2), 1021 \mathrm{E}(5), 1021 \mathrm{~F}(1), 1021 \mathrm{FA}(1), 1021 \mathrm{FA}(2), 1021 \mathrm{FB}(1), 1021 \mathrm{FB}(2)$, $1021 \mathrm{FB}(3), 1021 \mathrm{FB}(6), 1021 \mathrm{G}(2), 1021 \mathrm{H}(1), 1021 \mathrm{I}(1), 1021 \mathrm{~J}(1), 1021 \mathrm{~J}(2), 1021 \mathrm{~J}(3), 1021 \mathrm{~K}(1), 1021 \mathrm{~L}(1)$, $1021 \mathrm{~L}(2), 1021 \mathrm{M}(1), 1021 \mathrm{M}(3), 1021 \mathrm{~N}, 1021 \mathrm{NA}(1), 1021 \mathrm{NA}(2), 1021 \mathrm{NA}(3), 1021 \mathrm{NB}(1), 1021 \mathrm{NB}(2)$, $1021 \mathrm{NB}(3), 1021 \mathrm{O}(1), 1021 \mathrm{O}(3), 1021 \mathrm{P}(1), 1021 \mathrm{P}(2), 1021 \mathrm{P}(3), 1021 \mathrm{P}(4), 1021 \mathrm{P}(5), 1021 \mathrm{P}(6), 1023 \mathrm{P}(1)$, $1023 \mathrm{P}(2), 1023 \mathrm{P}(4), 1041 \mathrm{~A}, 1041 \mathrm{~B}(1), 1041 \mathrm{C}(1), 1041 \mathrm{D}, 1041 \mathrm{E}(1), 1041 \mathrm{~F}(1), 1041 \mathrm{G}, 1043 \mathrm{~A}(1), 1043 \mathrm{~A}(2)$, $1052 \mathrm{~B}(3), 1052 \mathrm{BA}(4), 1052 \mathrm{C}(6), 1070 \mathrm{~B}(1), 1070 \mathrm{C}(1), 1070 \mathrm{D}(3), 1071 \mathrm{~B}(2), 1071 \mathrm{E}, 1072 \mathrm{E}(11), 1072 \mathrm{H}(1)$, $1072 \mathrm{H}(3), 1072 \mathrm{H}(4), 1072 \mathrm{H}(5), 1072 \mathrm{H}(6), 1101 \mathrm{~B}(10), 1101 \mathrm{C}(1), 1101 \mathrm{C}(2), 1101 \mathrm{C}(3), 1101 \mathrm{E}(1), 1101 \mathrm{~F}(1)$, $1101 \mathrm{~F}(1 \mathrm{~A}), 1101 \mathrm{G}, 908 \mathrm{BA}(1), 908 \mathrm{BB}, 908 \mathrm{BQ}(1), 908 \mathrm{BR}(2), 908 \mathrm{BS}, 908 \mathrm{BV}(4), 908 \mathrm{DA}(3), 908 \mathrm{DB}(3)$, 921L(7), 921M(1), 921M(2), 921M(3), 921P(2), 922HC(3), 1054A(3), 1054B(4), 1054BA(4), 1058(1).

$17 \quad$ Troy Anderson, Commonwealth Criminal Law (Federation Press, $2^{\text {nd }}$ ed, 2018) 3.

18 Helen Bird and George Gilligan, 'Financial Services Misconduct and the Corporations Act 2001' (Working Paper No 2/2015, Centre for International Finance and Regulation, July 2015) 7. Ibid. 
broadly, are usually outcome-focused, and are capable of capturing new conduct that is not currently contemplated by the law (hence, 'general' offences). It is worth observing that the Royal Commission cautioned against an overly prescriptive approach to financial services regulation, ${ }^{20}$ and it has been argued that principle-based offences, as opposed to prescriptive ex ante rules, are particularly suited to the area of white-collar crime, where the 'type' of conduct that is rendered 'criminal' shifts over time in response to new technologies and evolving social norms. ${ }^{21}$ This preference is evident by the insertion of new, broadly drafted 'omnibus' provisions in the Criminal Code with respect to the offences of foreign bribery ${ }^{22}$ and general dishonesty. ${ }^{23}$

Given the dual meanings of the terms 'general' and 'specific', it follows that a 'specific' offence in its Corporations Act meaning (being an offence that is expressly provided for in a legislative provision), can also be a broadly drafted, norm-based provision (and thus, a 'general' offence as understood in its general criminal law meaning). Equally, a 'general' offence in its Corporations Act meaning (being an offence that is enlivened by s 1311 and is drafted without any express reference to it being an offence), can be narrowly tailored and specifically drafted (and hence, a 'specific' offence in its general criminal meaning). The potential confusion that may arise from the dual meaning of the terms may ultimately give weight to the adoption of alternative terms to describe the offences in the Corporations Act. However, for the purposes of this article the terms as defined by Bird and Gilligan are adopted.

This Part examines in detail the differences between a 'general' and 'specific' offence as defined by Bird and Gilligan. Although approaching an analysis of the offence provisions in ch 7 is assisted by dividing the offences into these two broad categories, as will be seen, even within this specific/general offence dichotomy, the legislature has failed to adopt a single or consistent drafting formula when inserting 'specific' or 'general' offences into ch 7.

20 See Australian Law Reform Commission, Review of the Legislative Framework for Corporations and Financial Services Regulation (Preliminary Analysis, December 2020) <https://www.alrc .gov.au/inquiry/review-of-the-legislative-framework-for-corporations-and-financial-services -regulation/inquiry-approach/2-preliminary-analysis/> ('ALRC Preliminary Analysis'). See also Final Report (n 4) 16 [1.5.3].

21 On norm-setting and the response of the criminal law in a white-collar setting, see generally Samuel Buell, "White Collar" Crimes' in Markus Dubber and Tatjana Hornle (eds), Oxford Handbook of Criminal Law (Oxford University Press, 2014) 837-50.

22 Criminal Code Act 1995 (Cth) ('Criminal Code') s 141.1 (Bribery of a Commonwealth Public Official).

23 Ibid s 135.1. Note, broad omnibus offences have been gradually inserted into federal statutes, including the Criminal Code, following the recommendation made in the Final Report of the Review of Commonwealth Criminal Law (the Gibbs Committee), handed down in December 1991. see Sir Harry Gibbs, Justice Raymond Watson and Archibald Menzies, Review of Commonwealth Criminal Law: Principles of Criminal Responsibility and Other Matters (Interim Report, 1990), cited in ALRC Final Report (n 14) 50 [2.6] 


\section{Specific Offence Provisions}

Specific offences in the Corporations Act are offences committed directly under legislative provisions. ${ }^{24}$ That is, specific offence provisions expressly provide that the doing, or not doing, of an act or thing forbidden or required is an offence. ${ }^{25} \mathrm{Of}$ the 299 offences in ch 7, 94 are specific offence provisions. ${ }^{26}$

Every specific offence in ch 7 contains the phrase 'commits an offence if'. The phrase is preceded by the relevant actor or 'wrongdoer', which, for the large majority of specific offences is 'a person', broadly defined to include a body corporate, ${ }^{27}$ partnership and multiple trustees. ${ }^{28}$ However, it can also be a 'a regulated person', 29 'the responsible person', ${ }^{30}$ 'the issuer of a financial product', ${ }^{31}$ 'an issuer or seller of financial products', ${ }^{32}$ a 'financial services licensee', 33 an 'authorised representative of a financial services licensee', 34 or 'the providing entity' ${ }^{35}$ Each of these different terms is the subject of separate and qualified definitions, a comprehensive analysis of which is beyond the scope of this article. ${ }^{36}$

The taxonomy of specific offences has not been satisfactorily documented or explained. Although all specific offences contain the phrase 'commits an offence if', a review of the specific offences in ch 7 reveals that the legislature has used two different drafting formulas. Distinguishing between these two drafting formulas is critical to locating specific offences in ch 7 as well as to identifying the penalties that attach to them. This section defines these formulas and examines their application throughout ch 7.

$24 \quad$ Bird and Gilligan (n 18) 7.

25 Ibid. Specific offences are to be contrasted with general offences, which are not offences per se and are only made offences by virtue of the operation of s 1311. See below Part II(A)(3).

26 See Corporations Act (n 1) ss 952C(1), 952C(3), 952D(1), 952D(2), 952E(6), 952F(2), 952F(3), 952F(4), 952G(2), 952G(4), 952G(6), 952H(2), 952I(1), 952I(2), 952I(3), 952I(4), 952J(1), 952K, 952L(1), 952L(2), 952L(3), 952M, 989CA(3), 989CA(4), 993B(1), 993B(3), 993C(1), 993C(3), 993D(2), 993D(3), 1020AI(3), 1020AI(5), 1020AI(7), 1020AJ, 1020B(2), 1021C(1), 1021C(3), 1021D(1), $1021 \mathrm{D}(2), 1021 \mathrm{E}(5), 1021 \mathrm{~F}(1), 1021 \mathrm{FA}(1), 1021 \mathrm{FA}(2), 1021 \mathrm{FB}(1), 1021 \mathrm{FB}(2), 1021 \mathrm{FB}(3), 1021 \mathrm{FB}(6)$, $1021 \mathrm{G}(2), 1021 \mathrm{H}(1), 1021 \mathrm{I}(1), 1021 \mathrm{~J}(1), 1021 \mathrm{~J}(2), 1021 \mathrm{~J}(3), 1021 \mathrm{~K}(1), 1021 \mathrm{~L}(1), 1021 \mathrm{~L}(2), 1021 \mathrm{M}(1)$, $1021 \mathrm{M}(3), 1021 \mathrm{~N}, 1021 \mathrm{NA}(1), 1021 \mathrm{NA}(2), 1021 \mathrm{NA}(3), 1021 \mathrm{NB}(1), 1021 \mathrm{NB}(2), 1021 \mathrm{NB}(3), 1021 \mathrm{O}(1)$, $1021 \mathrm{O}(3), 1021 \mathrm{P}(1), 1021 \mathrm{P}(2), 1021 \mathrm{P}(3), 1021 \mathrm{P}(4), 1021 \mathrm{P}(5), 1021 \mathrm{P}(6), 908 \mathrm{BA}(1), 908 \mathrm{BB}, 908 \mathrm{BQ}(1)$, 908BR(2), 908BS, 908BV(4), 908DA(3), 908DB(3), 921L(7), 921M(1), 921M(2), 921M(3), 921P(2), $922 \mathrm{HC}(3), 1054 \mathrm{~A}(3), 1054 \mathrm{~B}(4), 1054 \mathrm{BA}(4), 1058(1)$.

Acts Interpretation Act 1901 (Cth) s 2C.

See Corporations Act (n 1) ss 761A, 761F, 761FA.

See, eg, ibid ss 1020AI(3), 1020AI(5).

See, eg, ibid s $1021 \mathrm{~N}$.

See, eg, ibid s 1021FB(1).

See, eg, ibid s 1021O(1).

See, eg, ibid s 952D(1).

See, eg, ibid s 952K.

See, eg, ibid s 952C.

Joe Longo, 'Market Misconduct Provisions of the Financial Services Reform Act: Challenges for Market Regulation' (Conference Paper, Centre for Corporate Law and Securities Regulation Seminar, 25 July 2001) 7. 


\section{(a) Formula One: Specific Offence with Penalty Specified}

The first formula ('formula one') contains the phrase 'commits an offence if', and the penalty attaching to the offence is specified in a provision of the Corporations Act. There are 18 formula-one specific offences in ch 7.37

While formula-one specific offences are clearly drafted on the face of the provision, they are the hardest to find. This is because formula-one specific offences are the only offences in ch 7 that are not listed in sch 3 (sch 3 being a consolidated list of 'penalties' that attach to offence provisions in the Corporations $A c t)$. As a result, the only way to 'find' a formula-one specific offence is to locate the provision itself, which, given the size and scope of the Corporations Act, is not an easy task. In contrast, the 281 other offences in ch 7 (comprising formula-two specific offences and general offences, on which more below) can be immediately identified by scanning sch 3. Due to the convenience of sch 3, it is often used as a proxy list, or reference sheet, to identify offences in the Corporations Act. This reliance on sch 3 as a proxy list, however, means that formula-one specific offences can be (and often are) overlooked.

Although all formula-one specific offences are alike in that the penalty for the offence is not listed in sch 3, formula-one specific offences can be further divided into two sub-species by reference to where the penalty is otherwise specified. Section 1311E provides that when a penalty is not specified in sch 3, it may be specified either in the offence provision itself, or 'any other provision of the Act'. Of the 18 formula-one specific offences in ch 7, the penalty for 16 of them is articulated in the offence provision itself. Section 908BA is an example of a formula-one specific offence with the penalty specified in the offence provision itself. Relevantly, it provides:

908BA Administrators of significant financial benchmarks must be licensed

(1) A person commits an offence if:

(a) the person:

(i) administers a significant financial benchmark; or

(ii) holds out that the person administers a significant financial benchmark; and

(b) the person does not hold a benchmark administrator licence that specifies the financial benchmark; and

(c) the period applying under subsection (2) for the financial benchmark has ended.

Penalty: 5 years imprisonment. ${ }^{38}$ 908DB(3), 921L(7), 921M(1), 921M(2), 921M(3), 921P(2), 922HC(3), 1054A(3), 1054B(4), 1054BA(4), 1058(1).

$38 \quad$ Emphasis added. 
For the remaining two formula-one specific offences - those being ss 908DA(3) and $908 \mathrm{DB}(3)$ - the penalty is specified in a provision of the Act other than the offence provision itself. For both of those provisions, the penalty is specified in s 908DC, which appears directly beneath those two offence provisions in the Corporations Act. Relevantly, s 908DC provides as follows:

\section{DC Penalties for offences against this Division}

The penalty for an offence against this Division is 15 years imprisonment.

Evidently, s 908DC specifies the penalty for all offences 'against this Division', that being ch $7 \mathrm{pt} 7.5 \mathrm{~B}$ div 4 of the Act. No other division of ch 7 is structured in this way. The effect of $\mathrm{s} 908 \mathrm{DC}$ is that all of the offences in the division (those being ss $908 \mathrm{DA}(3)$ and $908 \mathrm{DB}(3)$ ) are dealt with as a single 'scheme'.

The offences in ss 908DA(3) and 908DB(3) were introduced as part of the Treasury Laws Amendment (2017 Measures No 5) Act 2018 (Cth), which received royal assent on 11 April 2018. Apart from being new offence provisions added to ch 7 on an ad hoc basis, there appears to be no policy justification for why the penalties for those two formula-one specific offences are not specified in the two offence provisions themselves, as is the case for the 16 other formula-one specific offences. It is unclear why this inconsistency in structure was introduced and whether it will continue in further amendments to the Corporations Act.

\section{(b) Formula Two: Specific Offence with No Penalty Specified}

The second formula ('formula two') also contains the phrase 'commits an offence if', but the penalty attaching to the offence is neither specified in the offence provision itself nor in any other provision of the Corporations Act. Rather, for formula-two specific offences, the penalty is specified in sch $3 .{ }^{39}$ There are 76 formula-two specific offences in ch $7 .^{\circ}$ An example of a formula-two specific offence in ch 7 is s $1021 \mathrm{~N}$ :

$1021 \mathrm{~N}$ Offence of failing to provide additional information requested under section 1017A

A person (the responsible person) commits an offence if:

Ibid S 1311E(1)(a).

Ibid ss $920 \mathrm{C}(3), 922 \mathrm{M}(3), 952 \mathrm{C}(1), 952 \mathrm{C}(3), 952 \mathrm{D}(1), 952 \mathrm{D}(2), 952 \mathrm{E}(6), 952 \mathrm{~F}(2), 952 \mathrm{~F}(3)$, 952F(4), 952G(2), $952 \mathrm{G}(4), 952 \mathrm{G}(6), 952 \mathrm{H}(2), 952 \mathrm{I}(1), 952 \mathrm{I}(2), 952 \mathrm{I}(3), 952 \mathrm{I}(4), 952 \mathrm{~J}(1), 952 \mathrm{~K}$ 952L(1), 952L(2), 952L(3), 952M, 989CA(3), 989CA(4), 993B(1), 993B(3), 993C(1), 993C(3), 993D(2), 993D(3), 1020AI(3), 1020AI(5), 1020AI(7), 1020AJ, 1020A(4), 1020B(2), 1021C(1), $1021(\mathrm{C})(3), 1021 \mathrm{D}(1), 1021 \mathrm{D}(2), 1021 \mathrm{E}(5), 1021 \mathrm{~F}(1), 1021 \mathrm{FA}(1), 1021 \mathrm{FA}(2), 1021 \mathrm{FB}(1), 1021 \mathrm{FB}(2)$, $1021 \mathrm{FB}(3), 1021 \mathrm{FB}(6), 1021 \mathrm{G}(2), 1021 \mathrm{H}(1), 1021 \mathrm{I}(1), 1021 \mathrm{~J}(1), 1021 \mathrm{~J}(2), 1021 \mathrm{~J}(3), 1021 \mathrm{~K}(1), 1021 \mathrm{~L}(1)$, $1021 \mathrm{~L}(2), 1021 \mathrm{M}(1), 1021 \mathrm{M}(3), 1021 \mathrm{~N}, 1021 \mathrm{NA}(1), 1021 \mathrm{NA}(2), 1021 \mathrm{NA}(3), 1021 \mathrm{NB}(1), 1021 \mathrm{NB}(2)$, 1021NB(3), 1021O(1), 1021O(3), 1021P(1), 1021P(2), 1021P(3), 1021P(4), 1021P(5), 1021P(6). 
(a) a request is made to them by another person, in accordance with subsection $1017 \mathrm{~A}(1)$, to provide further information about a financial product; and

(b) the responsible person is required by subsection $1017 \mathrm{~A}(2)$ to give the other person the information; and

(c) the other person has paid any charge in respect of the request, being a charge that is in accordance with subsections 1017A(5) and (6); and

(d) the responsible person does not take reasonable steps to ensure that, as soon as practicable after receiving the request, and in any event within one month, the information is provided to the other person in accordance with subsection $1017 \mathrm{~A}(4)$.

Many of the formula-two specific offences appear under sub-headings, which label the offence as being either a 'strict liability offence', 'fault-based offence' or 'ordinary offence'..$^{41}$ As discussed further below, ${ }^{42}$ the formula-two specific offences that contain these 'labels' sit on enforcement tracks. ${ }^{43}$ The remaining formula-two specific offences, which contain no 'labels' and do not sit on an enforcement track, are, for want of a better term, 'basic' formula-two specific offences (see for example, s 1021N, extracted above). 44

\section{General Offence Provisions}

General offence provisions are quite different machines to specific offences. Rather than the prohibited conduct being expressly classified as an offence by the provision itself (as is the case with specific offences), general offences are made offences 'by virtue of' s 1311(1) of the Corporations Act. Section 1311(1) provides that a person who either (a) does an act or thing that is forbidden by a provision of the Act; (b) does not do an act or thing that the person is required to do by a provision of the Act; or (c) otherwise contravenes a provision of the Act, is guilty of an offence.

Accordingly, unlike specific offence provisions, general offence provisions do not, on their face, make plain that they are indeed an offence provision. There are a total of 205 general offences in ch 7.45 An example is s 911A(1):

See, eg, ibid s 952C(1) (offence of strict liability), s 952C(3) (ordinary offence) and s 920C(3) (faultbased offence).

See below Part II(A)(3).

See, eg, s 1021O, extracted in Part II(b)(i) below and accompanying discussion.

Note that a 'basic' formula-two specific offence is intended to be a reference to a formula-two specific offence without a label of either 'strict liability offence', 'ordinary offence' or 'fault-based offence'.

45 Corporations Act (n 1) ss 791A(1), 791B, 792B(1), 792B(2), 792B(3), 792B(4), 792B(5), 792C(1), 792D(1), 792E, 792F(1), 792F(2), 792F(3), 792G(1), 792G(2), 792I, 793D(3), 794B(3), 798C(3), 798C(6), 794D(3), 794E(2), 798D(4), 798DA(4), 820A(1), 820B, 821B(1), 821B(2), 821B(3), 


\section{A Need for an Australian financial services licence}

(1) Subject to this section, a person who carries on a financial services business in this jurisdiction must hold an Australian financial services licence covering the provision of the financial services.

Note 2: Failure to comply with this subsection is an offence (see subsection 1311(1)).

Evidently, s 911A(1) does not exhibit the structural attributes of an offence provision (ie, fault elements or criminal penalty). That is because s 911A(1) merely specifies the 'conduct' that a financial services business is required to do - the criminal offence only arises by operation of $s$ 1311(1) in combination with that specified conduct. Anderson comments that "[m]any of the "offences" in the Corporations Act are not "offences" per se, but rather the offence comes about by virtue of s 1311(1)'. ${ }^{46}$ Similarly, the Full Federal Court, in Australian Securities and Investment Commission $v$ Whitebox Trading Pty Ltd,47 held that provisions like $911 \mathrm{~A}(1)$, when construed independently of s 1311(1), have the effect of merely 'creating statutory norms which prohibit particular conduct, but do not themselves specify any ... criminal consequences for a breach' ${ }^{48}$

Some assistance in identifying general offences is provided by notations. For example, the notation, '[f]ailure to comply with this subsection is an offence (see subsection 1311(1))', appears underneath s 911A(1). However, such notations do not always appear under a provision that is made a general offence by the operation of s 1311(1). For example, notations do not appear under ss 1012DA(9) or 1012DAA(10), ${ }^{49}$ notwithstanding that both provisions are made general offences by virtue of $s$ 1311(1). It is likely that the omission of notations in these two

\footnotetext{
$821 \mathrm{~B}(4), 821 \mathrm{BA}(1), 821 \mathrm{C}(1), 821 \mathrm{C}(3), 821 \mathrm{D}, 821 \mathrm{E}(1), 821 \mathrm{E}(2), 821 \mathrm{E}(3), 822 \mathrm{D}(3), 823 \mathrm{~B}(3), 823 \mathrm{D}(5)$, $823 \mathrm{E}(3), 850 \mathrm{C}, 851 \mathrm{D}(8), 852 \mathrm{~B}(2), 853 \mathrm{~F}(1), 853 \mathrm{~F}(2), 854 \mathrm{~A}(4), 892 \mathrm{~B}(1), 892 \mathrm{~B}(3), 892 \mathrm{H}(1), 892 \mathrm{H}(2)$, $892 \mathrm{H}(3), 892 \mathrm{H}(6), 892 \mathrm{H}(7), 892 \mathrm{~K}(2), 904 \mathrm{~B}(1), 904 \mathrm{~B}(5), 904 \mathrm{C}(1), 904 \mathrm{C}(3), 904 \mathrm{D}(2), 904 \mathrm{E}$, 904G(5), 904H(3), 904K(4), 905A(2), 907A, 911A(1), 911B(1), 911C, 912C(3), 912D(1B), 912D(2), $912 \mathrm{E}(1), 912 \mathrm{~F}(1), 916 \mathrm{~A}(3 \mathrm{~A}), 916 \mathrm{~B}(2 \mathrm{~A}), 916 \mathrm{~B}(5 \mathrm{~A}), 916 \mathrm{C}(3), 916 \mathrm{D}(2 \mathrm{~A}), 916 \mathrm{~F}(1), 916 \mathrm{~F}(1 \mathrm{~A}), 916 \mathrm{~F}(3)$, 916G(2), 916G(3), 923A(1), 923B(1), 923C(1), 923C(2), 942B(8), 942C(8), 942E, 943F, 946AA(4), $946 \mathrm{~B}(3 \mathrm{~A}), 946 \mathrm{~B}(9), 949 \mathrm{~A}(2), 949 \mathrm{~A}(5), 949 \mathrm{~B}(2), 949 \mathrm{~B}(4), 982 \mathrm{C}(1), 982 \mathrm{C}(2), 982 \mathrm{D}, 983 \mathrm{C}, 984 \mathrm{~B}(1)$, 985D(1), 985J(1), 985J(2), 985J(4), 985K(1), 988A(1), 989B(1), 989B(2), 989B(3), 990B(1), 990B(2), 990B(6), 990D(1), 990D(2), 990F(a), 990I(3), 990K(1), 991B(2), 991E(1), 991E(3), $991 \mathrm{~F}(1), 991 \mathrm{~F}(2), 991 \mathrm{~F}(3), 992 \mathrm{~A}(1), 992 \mathrm{~A}(3), 992 \mathrm{AA}(1), 1012 \mathrm{DA}(9), 1012 \mathrm{DAA}(10), 1012 \mathrm{H}(2)$, 1013I(4), 1013IA(5), 1013K(1), 1013K(2), 1015B(1), 1015D(2), 1015D(3), 1015D(4), 1015E(1), 1016A(2), $1016 \mathrm{~A}(3), 1016 \mathrm{~B}(1), 1016 \mathrm{C}, 1016 \mathrm{D}(1), 1016 \mathrm{D}(2)(\mathrm{d}), 1016 \mathrm{E}(2), 1017 \mathrm{~B}(1), 1017 \mathrm{C}(2), 1017 \mathrm{C}(2 \mathrm{~A}), 1017 \mathrm{C}(3)$, $1017 \mathrm{C}(3 \mathrm{~A}), 1017 \mathrm{C}(5), 1017 \mathrm{D}(1), 1017 \mathrm{DA}(3), 1017 \mathrm{E}(3), 1017 \mathrm{E}(4), 1017 \mathrm{~F}(2), 1017 \mathrm{G}(1), 1018 \mathrm{~A}(1)$, $1018 \mathrm{~A}(2), 1018 \mathrm{~B}(1), 1020 \mathrm{AB}(3), 1020 \mathrm{AC}(2), 1020 \mathrm{AD}(2), 1020 \mathrm{AE}, 1020 \mathrm{BAA}(1), 1020 \mathrm{E}(8), 1020 \mathrm{E}(9)$, $1023 \mathrm{P}(1), 1023 \mathrm{P}(2), 1023 \mathrm{P}(4), 1041 \mathrm{~A}, 1041 \mathrm{~B}(1), 1041 \mathrm{C}(1), 1041 \mathrm{D}, 1041 \mathrm{E}(1), 1041 \mathrm{~F}(1), 1041 \mathrm{G}, 1043 \mathrm{~A}(1)$, $1043 \mathrm{~A}(2), 1052 \mathrm{~B}(3), 1052 \mathrm{BA}(4), 1052 \mathrm{C}(6), 1070 \mathrm{~B}(1), 1070 \mathrm{C}(1), 1070 \mathrm{D}(3), 1071 \mathrm{~B}(2), 1071 \mathrm{E}, 1072 \mathrm{E}(11)$, $1072 \mathrm{H}(1), 1072 \mathrm{H}(3), 1072 \mathrm{H}(4), 1072 \mathrm{H}(5), 1072 \mathrm{H}(6), 1101 \mathrm{~B}(10), 1101 \mathrm{C}(1), 1101 \mathrm{C}(2), 1101 \mathrm{C}(3), 1101 \mathrm{E}(1)$, $1101 \mathrm{~F}(1), 1101 \mathrm{~F}(1 \mathrm{~A}) .1101 \mathrm{G}$.

Anderson (n 17) 104.

(2017) 251 FCR 448.

ASIC $v$ Whitebox Trading Pty Ltd (2017) 251 FCR 448, 457 (Allsop CJ, Middleton and Bromwich JJ). Other examples in the Corporations Act outside of ch 7 include ss 142(1) and 142(2).
} 
instances was inadvertent, given that the Explanatory Memorandum introducing the Financial Services Reform Bill 2001 (Cth) asserted that 'to ensure that it is clear when a provision is subject to a criminal penalty ... [n]otes have been placed under all provisions where offences are created through subsection 1311(1)'.50 The oversight, however, is a significant one, when considering that both provisions constitute indictable offences with maximum penalties of up to two years imprisonment (or 2,400 penalty units for a body corporate)..$^{51}$

\section{Specific and General Offences on Enforcement Tracks}

'Enforcement tracks' provide a regulator with multiple options to sanction the same contravening conduct. They are designed to ensure that the regulatory response is proportionate to the severity of the misconduct being sanctioned. Enforcement tracks were recently endorsed by the ASIC Enforcement Taskforce Review, which concluded that 'it is important that ASIC have a range of options for enforcement to enable it to respond adequately in circumstances of individual cases' ${ }^{52}$ Enforcement tracks appear regularly throughout ch 7. The most common 'track' is one that makes the same contravening conduct sanctionable by either a civil penalty or a criminal offence; 53 however, as explored below, other types of enforcement tracks (even if they have not previously been defined as such) also appear in ch 7.

The inclusion of enforcement tracks in ch 7 compounds the complexity that results from the inconsistent way in which offence provisions in ch 7 have been drafted. To demonstrate, because there is no single drafting formula for an offence provision in ch 7, the legislature has inserted different types of enforcement tracks to fit the drafting style of each type of offence. Accordingly, as shown in Table 1 below, there are three different types of enforcement tracks: (1) 'dual-track provisions' on which general offences sit; (2) 'scheme dual track' provisions on which formula-one specific offences sit; and (3) 'multiple-track provisions' on which formula-two specific offences sit.

50 Explanatory Memorandum, Financial Services Reform Bill 2001 (Cth) 46 [6.111] ('EM Financial Reform Bill').

$51 \quad$ Maximum penalty in penalty units applicable to a body corporate obtained using conversion formula specified in s 311C(2)(b) of the Corporations Act 2001 (Cth). See also below at Part II(C)(1).

52 ASIC Enforcement Review Taskforce, Department of Treasury and Finance (Cth), Positions Paper 7 - Strengthening Penalties for Corporate and Financial Misconduct (2017) 8 [12] ('ASIC Taskforce'). Enforcement tracks were also examined in some detail by the ALRC as part of its review into Australia's corporate criminal responsibility regime. See ALRC Final Report (n 14) 175-7 [5.24]; Australian Law Reform Commission, Corporate Criminal Responsibility (Discussion Paper No 87, November 2019) 92 [4.20] ('ALRC Discussion Paper').

53 Dual-track provisions are not unique to the Corporations Act and also appear, for example, in ss 45AF, 45AJ, 45AG and 45AK of the Competition and Consumer Act 2010 (Cth). 
Table 1: Enforcement Tracks in Chapter 7

\begin{tabular}{|l|l|}
\hline \multicolumn{1}{|c|}{ Offence Type } & \multicolumn{1}{|c|}{ Enforcement Mechanism } \\
\hline General & Dual track \\
\hline Specific (Formula one) & Scheme dual track \\
\hline Specific (Formula two) & Multiple track \\
\hline
\end{tabular}

The following section examines the key features of each enforcement track. These different tracks have never previously been examined.

\section{(a) General Offence: Dual Track}

It is easiest to start with general offence 'dual-track' provisions. Of the 205 general offences in ch 7,54 13 sit on what are described as dual-track provisions. ${ }^{55}$ These specify that a breach can constitute either an offence (by virtue of s 1311(1) operating), or a civil penalty (by virtue of s 1317E attaching), or both. For these dual-track provisions, the conduct that is prohibited is the same for both the civil penalty and the criminal offence. Dual-track provisions are marked by notations as exemplified by s $1023 \mathrm{P}(1)$ :

\section{P Enforcement of product intervention orders}

(1) A person must not engage in conduct contrary to a product intervention order that is in force in relation to the person.

54 See Corporations Act (n 1) ss 791A(1), 791B, 792B(1), 792B(2), 792B(3), 792B(4), 792B(5), 792C(1), 792D(1), 792E, 792F(1), 792F(2), 792F(3), 792G(1), 792G(2), 792I, 793D(3), 794B(3), 798C(3), 798C(6), 794D(3), 794E(2), 798D(4), 798DA(4), 820A(1), 820B, 821B(1), 821B(2), 821B(3), $821 \mathrm{~B}(4), 821 \mathrm{BA}(1), 821 \mathrm{C}(1), 821 \mathrm{C}(3), 821 \mathrm{D}, 821 \mathrm{E}(1), 821 \mathrm{E}(2), 821 \mathrm{E}(3), 822 \mathrm{D}(3), 823 \mathrm{~B}(3), 823 \mathrm{D}(5)$, $823 \mathrm{E}(3), 850 \mathrm{C}, 851 \mathrm{D}(8), 852 \mathrm{~B}(2), 853 \mathrm{~F}(1), 853 \mathrm{~F}(2), 854 \mathrm{~A}(4), 892 \mathrm{~B}(1), 892 \mathrm{~B}(3), 892 \mathrm{H}(1), 892 \mathrm{H}(2)$, $892 \mathrm{H}(3), 892 \mathrm{H}(6), 892 \mathrm{H}(7), 892 \mathrm{~K}(2), 904 \mathrm{~B}(1), 904 \mathrm{~B}(5), 904 \mathrm{C}(1), 904 \mathrm{C}(3), 904 \mathrm{D}(2), 904 \mathrm{E}$, 904G(5), 904H(3), 904K(4), 905A(2), 907A, 911A(1), 911B(1), 911C, 912C(3), 912D(1B), 912D(2), 912E(1), 912F(1), 916A(3A), 916B(2A), 916B(5A), 916C(3), 916D(2A), 916F(1), 916F(1A), 916F(3), 916G(2), 916G(3), 923A(1), 923B(1), 923C(1), 923C(2), 942B(8), 942C(8), 942E, 943F, 946AA(4), 946B(3A), 946B(9), 949A(2), 949A(5), 949B(2), 949B(4), 982C(1), 982C(2), 982D, 983C, 984B(1), 985D(1), 985J(1), 985J(2), 985J(4), 985K(1), 988A(1), 989B(1), 989B(2), 989B(3), 990B(1), 990B(2), 990B(6), 990D(1), 990D(2), 990F(a), 990I(3), 990K(1), 991B(2), 991E(1), 991E(3), $991 \mathrm{~F}(1), 991 \mathrm{~F}(2), 991 \mathrm{~F}(3), 992 \mathrm{~A}(1), 992 \mathrm{~A}(3), 992 \mathrm{AA}(1), 1012 \mathrm{DA}(9), 1012 \mathrm{DAA}(10), 1012 \mathrm{H}(2)$, 1013I(4), 1013IA(5), 1013K(1), 1013K(2), 1015B(1), 1015D(2), 1015D(3), 1015D(4), 1015E(1), 1016A(2), $1016 \mathrm{~A}(3), 1016 \mathrm{~B}(1), 1016 \mathrm{C}, 1016 \mathrm{D}(1), 1016 \mathrm{D}(2)(\mathrm{d}), 1016 \mathrm{E}(2), 1017 \mathrm{~B}(1), 1017 \mathrm{C}(2), 1017 \mathrm{C}(2 \mathrm{~A}), 1017 \mathrm{C}(3)$, $1017 \mathrm{C}(3 \mathrm{~A}), 1017 \mathrm{C}(5), 1017 \mathrm{D}(1), 1017 \mathrm{DA}(3), 1017 \mathrm{E}(3), 1017 \mathrm{E}(4), 1017 \mathrm{~F}(2), 1017 \mathrm{G}(1), 1018 \mathrm{~A}(1)$, $1018 \mathrm{~A}(2), 1018 \mathrm{~B}(1), 1020 \mathrm{AB}(3), 1020 \mathrm{AC}(2), 1020 \mathrm{AD}(2), 1020 \mathrm{AE}, 1020 \mathrm{BAA}(1), 1020 \mathrm{E}(8), 1020 \mathrm{E}(9)$, $1023 \mathrm{P}(1), 1023 \mathrm{P}(2), 1023 \mathrm{P}(4), 1041 \mathrm{~A}, 1041 \mathrm{~B}(1), 1041 \mathrm{C}(1), 1041 \mathrm{D}, 1041 \mathrm{E}(1), 1041 \mathrm{~F}(1), 1041 \mathrm{G}, 1043 \mathrm{~A}(1)$, $1043 \mathrm{~A}(2), 1052 \mathrm{~B}(3), 1052 \mathrm{BA}(4), 1052 \mathrm{C}(6), 1070 \mathrm{~B}(1), 1070 \mathrm{C}(1), 1070 \mathrm{D}(3), 1071 \mathrm{~B}(2), 1071 \mathrm{E}, 1072 \mathrm{E}(11)$, $1072 \mathrm{H}(1), 1072 \mathrm{H}(3), 1072 \mathrm{H}(4), 1072 \mathrm{H}(5), 1072 \mathrm{H}(6), 1101 \mathrm{~B}(10), 1101 \mathrm{C}(1), 1101 \mathrm{C}(2), 1101 \mathrm{C}(3), 1101 \mathrm{E}(1)$, $1101 \mathrm{~F}(1), 1101 \mathrm{~F}(1 \mathrm{~A}), 1101 \mathrm{G}$.

55 Ibid ss 985J(1), 985J(2), 985J(4), 985K(1), 1023P(1), 1023P(2), 1023P(4), 1041A, 1041B, 1041C(1), 1041D, 1043A(1), 1043A(2). 
Note 1: Failure to comply with this subsection is an offence (see subsection 1311(1)).

Note 2: This subsection is also a civil penalty provision (see section 1317E). For relief from liability to a civil penalty relating to this subsection, see section $1317 \mathrm{~S}$.

Of the 13 dual-track provisions in ch 7, 10 provide the regulator with a choice between a fault-based criminal offence or a civil penalty provision..$^{56}$ The remaining three, specifically ss $985 \mathrm{~J}(1),(2)$ and (4), provide options of a strict liability criminal offence or a civil penalty provision. As such, it may be said that there are two 'types' of dual-track provisions, those which contain fault based offences and those which contain strict liability offences.

\section{(b) Formula-Two Specific Offences: Multiple-Track Provisions}

The enforcement tracks that formula-two specific offences sit on may be described as 'multiple-track' provisions. They differ to the dual tracks on which general offence provisions sit in two main ways. First, these multiple tracks are expressly drafted into the provision. That is, the different sanctions that may attach to a contravention of the provision (ie, strict liability, civil penalty, etc) are drafted into separate subsections of the provision. This is to be contrasted to a 'dual-track' provision (like s 1023P above), which either operates as a general offence provision or as a civil penalty provision by virtue of its interaction with either s 1311(1) or s 1317E. Secondly, multiple tracks are not limited to two (or dual) tracks but offer the regulator multiple different combinations of enforcement options. Specifically, there are four different combinations of enforcement options provided to regulators in ch 7 by virtue of these multiple-track provisions.

In specifying these four different multiple tracks, drafters of the legislation have inserted formula-two specific offences into ch 7 under various different 'labels', each denoting a different type of criminal offence. As noted above, ${ }^{57}$ whenever a formula-two specific offence sits on a multiple track the offence has a sub-heading labelling the offence as either a 'strict liability offence', 'ordinary offence', or 'fault-based offence'. Whereas the term 'strict liability offence' appears throughout the Corporations Act, the terms 'fault-based offence' and 'ordinary offence' are unique to formula-two specific offences. Although neither term is defined in the Corporations Act, both are forms of mens rea offences (that is offences which contain a fault element), ${ }^{58}$ and appear only to be distinguishable by the 'type' of enforcement track on which they sit.

\footnotetext{
Ibid ss $985 \mathrm{~K}(1), 1023 \mathrm{P}(1), 1023 \mathrm{P}(2), 1023 \mathrm{P}(4), 1041 \mathrm{~A}, 1041 \mathrm{~B}, 1041 \mathrm{C}(1), 1041 \mathrm{D}, 1043 \mathrm{~A}(1), 1043 \mathrm{~A}(2)$. See above Part II(A)(1)(b).

The Criminal Code uses the term 'fault elements' in s 5.1 as opposed to the common law concept of 'mens rea'. The term 'fault elements' was adopted to 'displace ... the uncertainties of common law references to 'mens rea.' It is equivalent in meaning to the commonly employed textbook reference
} 
The four categories of multiple-track provisions, each being defined by the type of formula-two specific offences that fall within the category, are summarised below.

Table 2: Formula-Two Specific Offence Multiple Tracks

\begin{tabular}{|l|l|}
\hline \multicolumn{1}{|c|}{ Multiple-Track Provisions } & \multicolumn{1}{c|}{ Options } \\
\hline Criminal / criminal & $\begin{array}{l}\text { Strict liability offence } \\
\text { Ordinary offence }\end{array}$ \\
\hline Criminal / civil & Fault-based offence \\
& Civil liability \\
\hline Criminal / criminal / civil & Fault-based offence \\
& Strict liability offence \\
& Civil liability \\
\hline Criminal / criminal & Strict liability offence \\
& Fault-based offence \\
\hline
\end{tabular}

\section{(i) Criminal/Criminal Multiple Track}

The criminal/criminal multiple track creates alternatives between a 'strict liability offence' and an 'ordinary offence' for the same prohibited conduct. The provisions for each offence are identical, except that the default fault elements in s 5.6 of the Criminal Code (intention or recklessness) apply to the 'ordinary offence', and the maximum penalty that attaches to an 'ordinary offence' is greater than the maximum penalty that attaches to a 'strict liability offence'. ${ }^{59}$ There are seven criminal/criminal multiple tracks in ch 7 (creating 14 separate offences). ${ }^{60}$

The criminal/criminal multiple track applies to provisions regulating complex regulatory regimes. They enable technical contraventions to be sanctioned by way of a strict liability offence (which has no fault elements and is therefore easier to establish), while still allowing for intentional and egregious breaches to be punished with the full force of the criminal law. An example of the criminal/criminal multiple track is found in the stipulation of two formula-two specific offences - one a 'strict liability offence' and the other an 'ordinary offence' - in s 1021O(1) and (3):

to the 'mental element' in crime though 'fault' is more accurately descriptive': see AttorneyGeneral's Department (Cth), The Commonwealth Criminal Code: A Guide For Practitioners (Report, March 2002) 13 ('Criminal Code Pracitioners Guide').

$59 \quad$ See Anderson (n 17) 46.

60 See Corporations Act (n 1) ss 952C(2), 993B(1), 993C(1), 1020AI(3), 1021C(1), 1021M(1), 1021O(1); 952C(3), 993B(3), 993C(3), 1020AI(5), 1021C(3), 1021M(3), 1021O(3). 
10210 Offences of issuer or seller of financial product failing to pay money into an account as required

\section{Strict liability offence}

(1) An issuer or seller of financial products commits an offence if:

(a) the issuer or seller is required by subsection $1017 \mathrm{E}(2)$ to pay particular money into an account in accordance with that subsection; and

(b) the issuer or seller does not pay the money into an account in accordance with that subsection.

(2) An offence based on subsection (1) is an offence of strict liability.

Note: For strict liability, see section 6.1 of the Criminal Code.

Ordinary offence

(3) An issuer or seller of financial products commits an offence if:

(a) the issuer or seller is required by subsection $1017 \mathrm{E}(2)$ to pay particular money into an account in accordance with that subsection; and

(b) the issuer or seller does not pay the money into an account in accordance with that subsection.

\section{(ii) Criminal/Civil Multiple Track}

The criminal/civil multiple track creates alternatives between a 'fault-based offence' and a civil penalty provision for the same prohibited conduct. There are seven criminal/civil multiple-track provisions in ch $7 .{ }^{61}$ For these provisions, the content of the prohibition is the same for both the civil contravention and the criminal offence, except that s 5.6 of the Criminal Code operates to import the fault elements contained in the Criminal Code with respect to the 'fault-based offence'. 'Fault-based offences' operate in the same way as 'ordinary offences', the only distinction appearing to be that the legislature has opted to use 'fault-based offences' in conjunction with civil contraventions (on criminal/civil multipletracks), and to have placed 'ordinary offences' with 'strict liability offences' (on criminal/criminal multiple tracks, as above). An example of a criminal/civil multiple-track provision is s 1021G:

$1021 \mathrm{G}$ Financial services licensee failing to ensure authorised representative gives etc. disclosure documents or statements as required

Financial services licensee must ensure authorised representative gives etc. disclosure documents or statements as required 
(1) A financial services licensee contravenes this subsection if the licensee does not take reasonable steps to ensure that an authorised representative of the licensee complies with their obligations under this Part to give or communicate disclosure documents or statements as and when required by this Part.

Fault-based offence

(2) A person commits an offence if the person contravenes subsection (1). Civil liability

(3) A person contravenes this subsection if the person contravenes subsection (1).

Note: This subsection is a civil penalty provision (see section 1317E).

Criminal/civil multiple tracks were introduced by amendments to existing provisions in the Corporations Act following the ASIC Taskforce Enforcement Review. ${ }^{62}$

\section{(iii) Criminal/Criminal/Civil Multiple Track}

The criminal/criminal/civil multiple track includes, in order of severity, a 'faultbased offence', a 'strict liability offence', and a civil penalty provision, to sanction the same prohibited conduct. There is only one example of this multiple track in ch 7 , and that is s $993 \mathrm{D}$, which regulates failures to pay loan monies into 'an account' as required by the rules set out in s 982B(1). In this sense, s 993D provides the regulator with the most complete suite of civil and criminal enforcement options. Section 993D provides as follows:

\section{D Failing to pay loan money into an account as required}

Failing to pay loan money into account as required

(1) A financial services licensee contravenes this subsection if:

(a) the licensee is required by subsection $982 \mathrm{~B}(1)$ to pay particular money into an account in accordance with that subsection; and

(b) the licensee does not pay the money into an account in accordance with that subsection.

Fault-based offence

(2) A person commits an offence if the person contravenes subsection (1).

Strict liability offence

(3) A person commits an offence of strict liability if the person contravenes subsection (1).

62 These amendments were introduced by the Strengthening Penalties Bill ( $\mathrm{n}$ 11), which received royal assent on 13 March 2019. See, ASIC Taskforce Final Report (n 11) 90. 
Civil liability

(4) A person contravenes this subsection if the person contravenes subsection (1).

Note: This subsection is a civil penalty provision (see section 1317E).

\section{(iv) A Drafting Error or Interchangeable Tracks?}

Section 989CA gives rise to a possible fourth multiple track on which formulatwo specific offences may sit. It provides as follows:

\section{CA Audit to be conducted in accordance with auditing standards}

(1) If an individual auditor, or an audit company, conducts an audit of a profit and loss statement and balance sheet for the purposes of this Subdivision, the individual auditor or audit company must:

(a) conduct the audit in accordance with the auditing standards; and

(b) include in the audit report on the profit and loss statement, and balance sheet, any statements or disclosures required by the auditing standards.

(2) If an audit firm, or an audit company, conducts an audit of a profit and loss statement and balance sheet for the purposes of this Subdivision, the lead auditor for the audit or review must ensure that:

(a) the audit is conducted in accordance with the auditing standards; and

(b) the audit report on the profit and loss statement, and balance sheet, includes any statements or disclosures required by the auditing standards.

Fault-based offence

(3) A person commits an offence if the person contravenes subsection (1) or (2).

Strict liability offence

(4) A person commits an offence of strict liability if the person contravenes subsection (1) or (2).

Section 989CA is anomalous, in that it combines both a 'fault-based offence' and a 'strict liability offence' on the same track. Although the substantive effect is to create another criminal/criminal multiple track (by providing the regulator with the choice between a full mens rea or a strict liability offence), it is an outlier in that the criminal/criminal multiple tracks in ch 7 (such as s 10210 extracted above) have been drafted such that the mens rea offence is defined as an 'ordinary offence'. As noted above, ${ }^{63}$ if the only way to differentiate a 'fault-based offence' from an 'ordinary offence' is by reference to the type of multiple track on which each type of mens rea offence sits, then s 989CA breaks down that distinction. 
It is unclear what to make of s 989CA. It may be an example of a drafting error. Alternatively, it could be a sign that going forwards the legislature intends to use the 'fault-based offence' terminology interchangeably with, or in place of, 'ordinary offence' language. Relevantly, s 989CA was amended recently as part of the reforms introduced in February 2019 under the Strengthening Corporate Penalties Bill.

\section{(c) Formula-One: Specific Offence Scheme Dual Track}

As set out above at Part II(A)(1)(a), there are only 18 formula-one specific offences in ch 7. Relevantly, of these 18 offences, only two of them - ss 908DA(3) and 908DB(3) - sit on an enforcement track. Incidentally, these two formula-one specific offences are the only formula-one specific offences for which the penalty attaching to the offence are specified in a provision other than the actual offence provision itself. The enforcement track that these two offences sit on may be described as a 'scheme dual track'.

The scheme dual track provides the regulator with a choice between a mens rea criminal offence and a civil penalty provision. Although the enforcement options provided to a regulator by the scheme dual track are the same as the options provided by a 'dual-track provision' (on which general offences sit, see above at Part II(A)(3)(a)) and a 'criminal/civil multiple track' (on which formulatwo specific offences sit, see above at Part II(A)(3)(b)(ii)), the scheme dual track differs because the penalty that attaches to each of the offences in ss 908DA(3) and $908 \mathrm{DB}(3)$ (which is all of the offences in that Division of ch 7) is specified in a separate provision, being s 908DC. It is for this reason that the enforcement track is characterized as a 'scheme dual track'. Relevantly, s 908DC provides:

\section{DC Penalties for offences against this Division}

The penalty for an offence against this Division is 15 years imprisonment.

Note: However, sections 1311A to $1311 \mathrm{E}$ will apply in relation to the penalty in the usual way.

As observed in Part II(A)(1)(a) above, no adequate policy reason exists to explain why the offences in ss 908DA(3) and 908DB(3) are drafted differently to the other 16 formula-one specific offences in ch 7. Relevantly, the fact that ss 908DA(3) and $908 \mathrm{DB}(3)$ are the only two formula-one specific offences to sit on an enforcement track, also fails to explain the drafting formula adopted. This is because there is no logical reason why the enforcement track on which ss 908DA(3) and 908DB(3) sit could not have been achieved by drafting the provisions consistently with the other 16 formula-one specific offences (ie, by specifying the penalty for the offences expressly under the respective provision). Alternatively, rather than creating the anomaly of a 'scheme dual track', the same enforcement options could have been achieved by drafting ss 908DA(3) and 
908DB(3) as formula-two specific offences, which sit on a criminal/civil multiple track as described in Part II(A)(3)(b)(ii).

\section{How to Find Specific and General Offences in Chapter 7}

There is no quick way to find the offence provisions in ch 7. There is a tendency (at least amongst practitioners) to rely on sch 3, but that is an incomplete list it contains only 281 of the 299 offence provisions in ch 7 . This is because sch 3 lists the 'penalties' that attach to offence provisions (as opposed to listing 'offences'), and because the penalties for some offences, namely formula-one specific offences, are specified in the main body of the Corporations Act (as opposed to sch 3), and because offences can (although none do in ch 7) arise by default when there is no penalty specified for an offence provision at all. ${ }^{64}$

The key to finding offence provisions in ch 7 turns on where the penalty for an offence provision lies. There are three sections of the Corporations Act that are relevant to this exercise. The first is s 1311E, which holds that a penalty is either specified in a provision of the Corporations Act or listed in sch 3. The next is s 1311(1A), which holds that for 'general offences' in ch 7, penalties must be specified in sch 3 . The third is s $1311 \mathrm{~F}$, which holds that, where no penalty is specified, the offence is an offence of strict liability and a penalty of 20 penalty units applies. As set out below, the operation of these provisions differs depending on whether the offence is a specific or a general offence.

\section{(a) Finding Specific Offences}

Sections $1311 \mathrm{E}$ and $1311 \mathrm{~F}$ state that the penalty attaching to a specific offence can be listed in sch 3, in a provision of the Corporations Act (including the specific offence provision), or not listed at all. As the penalty for a formula-one specific offence is specified in a provision of the Corporations Act, only formula-two specific offences are listed in sch 3 . These formula-two specific offences can be found by reviewing sch 3 (although sch 3 does not differentiate between the specific and general offences that it lists).

Specific offences that are not listed in sch 3 may constitute formula-one specific offences, which specify the penalty in a provision of the Corporations Act, or they may be default strict liability offences, which arise by virtue of the operation of $\mathrm{s} 1311 \mathrm{~F}$ (if there is no penalty specified for the offence in either a provision of the Corporations Act or in sch 3). ${ }^{65}$ There are 18 formula-one specific offences in ch 7, and no default strict liability specific offences arising by virtue of

See Corporations Act (n 1) s 1311F.

Section $1311 \mathrm{~F}$ provides that specific offences in respect of which a penalty is not specified in either sch 3 or a provision of the Corporations Act is a strict liability offence carrying a default penalty of 20 penalty units. 
$\mathrm{S} 1311 \mathrm{~F}$. As the penalty that attaches to a formula-one specific offence or a s $1311 \mathrm{~F}$ default offence is not listed in sch 3, the only way to find these offences (or to confirm they do not exist, as is the case with the operation of $\mathrm{s} 1311 \mathrm{~F}$ ), is to search ch 7 of the Corporations Act. Given the size of ch 7, this is not an easy task.

\section{(b) Finding General Offences}

Penalties for general offences in ch 7 must be listed in sch 3. Section 1311(1A) holds that, for ch 7, a general offence can only be enlivened by s 1311(1) 'if a penalty, pecuniary or otherwise, is set out in Schedule 3'. As such, there is no need to examine ch 7 for general obligations that may be enlivened by s 1311(1). Further, as $\mathrm{s} 1311(1 \mathrm{~A})$ requires that all general offences in ch 7 be listed in sch 3, and noting that sch 3 comprises a list of 'penalties' for the provisions that it lists, s 1311(1A) has the effect of excluding the operation of s $1311 \mathrm{~F}$ from applying to any 'general offence' in ch 7. In other words, there cannot be a general offence in ch 7 unless there is a penalty for the offence specified in sch 3.

\section{B Different 'Types' of Specific and General Offences}

Although every offence in ch 7 is either a specific or a general offence, there are different 'types' of specific and general offences in ch 7. Specific and general offences may also be delineated along temporal lines, ie, between substantial (or 'static') and continuing offences on the one hand, or according to whether offences require the proof of fault elements, including full and partial strict and absolute liability offences, on the other hand. These alternative classifications are not mutually exclusive. For example, a fault-based offence may be either static or continuing. Key distinctions are considered below.

\section{Continuing Offences}

A continuing offence is a further offence that, in prescribed circumstances, attaches to a substantive offence provision (ie, a specific or general offence considered above), which contains a continuing obligation. An obligation in a substantive offence provision 'continues' if it falls within one of the two circumstances set out in s 1314(1) and (2) (which are considered further below). ${ }^{66}$ The objective of continuing offences is to incentivise compliance with a continuing obligation (or to ensure one is not relieved from complying with a continuing obligation) following an initial contravention. ${ }^{67}$

\footnotetext{
See below Part II(B)(1)(a).

Attorney-General' Department (Cth), A Guide to Framing Commonwealth Offences, Infringement Notices and Enforcement Powers ( $3^{\text {rd }}$ ed, 2011) 43 ('Framing Federal Offences').
} 
Like general offences, which are governed by s 1311(1), continuing offences are not offences per se, but arise by virtue of the interaction between s 1314(3) and the relevant substantive offence provision in which the continuing obligation exists. The penalty that attaches to a continuing offence is calculated at a per diem rate, being half a penalty unit multiplied by the number of days in the period for which the continuing act was not done. ${ }^{68}$

There are no notations under any of the substantive offence provisions in ch 7 to indicate when s 1314(3) applies (as there are when s 1311(1) attaches), nor is there a schedule or index, like sch 3 , which lists the offence provisions which contain continuing obligations to which s 1314(3) attaches. As such, the only way to determine whether s 1314(3) applies is to review the offence provisions and to identify a continuing obligation where it exists. This is notwithstanding the Commonwealth Attorney-General Department's Guide to Framing Federal Offences, which states that '[a] continuing offence should be clearly expressed so that a person is aware that a continued failure to comply will lead to further offences being committed'.69

\section{(a) Components of Section 1314 Continuing Offences}

There are two key components to continuing offences. The first component is timing, that is, 'when' s 1314(3) is enlivened. Section 1314(3) is not enlivened until after an initial conviction for the principal contravention of the substantive offence has been secured. Section 1314(3) makes this express, stating that a continuing offence occurs only if 'a person is or was first convicted of a substantive offence, or is or was convicted of a second or subsequent offence, in relation to failure to do the act'. ${ }^{70}$ Therefore, if a person is convicted for failing to do an act the subject of a continuing obligation (and the act remains undone), liability for a further continuing offence only runs from the time an initial conviction has been secured. ${ }^{71}$

The second component relates to the substantive offence provisions to which s 1314(3) attaches. Section 1314(3) only attaches to a substantive offence provision that contains a continuing obligation. There are two types of continuing obligations, which are set out in ss 1314(1) and (2) as follows:

Corporations Act (n 1) s 1314(5). It is interesting to observe that the penalties for a continuing offence are measured at a per diem rate whereas the penalties attaching to civil continuing contraventions (ie, continuing civil penalty breaches) pursuant to s 1317QA are not.

Framing Federal Offences (n 67) 43.

Corporations Act (n 1) s 1314(3) (emphasis added).

Ibid s 1314(3)(c)). Note that, to the extent that s 1314(1)(d) may appear to be inconsistent with this reading - that a conviction of a substantive offence must first be secured before a continuing offence is enlivened - s1314(1)(e) makes express that s 1314(3) applies and that it must be read in that context. 
(1) Where:

(a) by or under a provision, an act is or was required to be done within a particular period or before a particular time; and

(b) failure to do the act within that period or before that time constitutes an offence; and

(c) the act is not done within that period or before that time; then:

(d) the obligation to do the act continues, after that period has ended or that time has passed, and whether or not a person is or has been convicted of a primary substantive offence in relation to failure to do the act, until the act is done; and

(e) subsections (3) and (4) apply.

(2) Where:

(a) by or under a provision, an act is or was required to be done but neither a period nor a time for the doing of the Act is or was specified; and

(b) failure to do the act constitutes an offence; and

(c) a person is or has been convicted of a primary substantive offence in relation to failure to do the act;

then:

(d) the obligation to do the act continues, despite the conviction, until the act is done; and

(e) subsections (3) and (4) apply.

While both ss 1314(1) and (2) have the same objective - to make an obligation to do an act that is required to be done by a substantive offence provision 'continue' - they attach to different types of acts. That is, sub-s (1) operates to ensure that an obligation to do an act that is or was required to be done 'within a particular period or before a particular time' continues, whereas sub-s (2) attaches to an obligation to do an act that is required to be done, but for which 'neither a period nor a time for the doing of the Act is or was specified'. In other words, sub-s (1) relates to obligations to do acts that are time-specified in an offence provision, and sub-s (2) attaches to obligations to do acts that are not time-specified in an offence provision.

There is a further observation to be made with respect to these two continuing obligations, and that relates to the extent to which a conviction for an initial contravention of the substantive offence provision is required first before the act continues. As noted above, s 1314(3) specifies that a continuing offence is not enlivened until after an initial conviction for a contravention of the substantive offence provision has been secured. This, however, relates to when liability for a failure to do a an act is enlivened (or when s 1314(3) attaches), and is 
to be distinguished from when a 'continuing obligation' to do the 'act' begins to run. Relevantly, only continuing obligations that fall into s 1314(2) require that a conviction be secured for an initial contravention of the offence provision before the obligation to do the act continues (see s $1314(2)(\mathrm{e})$ ). This is because the acts caught by s 1314(2) are not time-specified, causing the legislature to use the event of an initial conviction as the marker (or event) that triggers the continuing of the obligation to perform the act. In contrast, the obligation to do an act regulated by s 1314(1) continues 'whether or not a person is or has been conviction of a primary substantive offence in relation to failure to do the act' (see s 1314(1)(d)). This is because, an obligation to do an act that is caught by s 1314(1) continues as soon as the 'particular period' specified for the doing of the act in the substantive offence provision lapses.

\section{(b) Intersection Between Section 1314 of the Corporations Act and Section $4 \mathrm{~K}$ of the Crimes Act}

Section 1314 is not to be confused with continuing offences under $\mathrm{s} 4 \mathrm{~K}$ of the Crimes Act. Relevantly, s 4K provides as follows:

\section{$4 \mathrm{~K}$ Continuing and multiple offences}

(1) Where, under a law of the Commonwealth, an act or thing is required to be done within a particular period or before a particular time, then, unless the contrary intention appears, the obligation to do that act or thing continues, notwithstanding that the period has expired or the time has passed, until the act or thing is done.

(2) Where a refusal or failure to comply with a requirement referred to in subsection (1) is an offence against a law of the Commonwealth, a person commits an offence in respect of each day during which the person refuses or fails to comply with that requirement, including the day of a conviction for any such offence or any later day.

When $\mathrm{s} 4 \mathrm{~K}$ is compared to $\mathrm{s} 1314$, three observations may be made. First, s $4 \mathrm{~K}(1)$ defines a continuing obligation in almost identical terms to $s 1314(1)$. That is, $\mathrm{S} 4 \mathrm{~K}(1)$, like $\mathrm{s} 1314(1)$, provides that where an 'act or thing is required to be done within a particular period or before a particular time' and that act is not done, then the 'obligation to do the act continues'. Secondly, $54 \mathrm{~K}$ contains no equivalent continuing obligation to $\mathrm{s} 1314(2)$. That is, $\mathrm{s} 4 \mathrm{~K}$ does not attach to offence provisions which require an act to be done, but which do not specify a particular period in which the act must be done. As a result, $\mathrm{s} 4 \mathrm{~K}$ attaches only to offences that require acts to be done within a particular period and is therefore narrower in its scope than s 1314. Thirdly, liability for a continuing offence arises sooner and more frequently under s $4 \mathrm{~K}(2)$ than it does under $\mathrm{s} 1314$. This is measurable in two ways: 
1. A continuing offence under $\mathrm{s} 4 \mathrm{~K}(2)$ arises as soon as the period in which the act is required to be done lapses and the act remains undone (ie, as soon as the act commences to continue). In contrast, under s 1314(3), liability does not arise until after an initial conviction with respect to the substantive offence provision has been secured; and

2. A separate continuing offence under s $4 \mathrm{~K}(2)$ arises for 'each day' that the obligation to do the act after the particular period has expired remains undone. In contrast, s 1314(3) creates a single further offence (or one continuing offence) for the entire continuing contravention period. $7^{72}$

It is necessary to draw out the differences between s $4 \mathrm{~K}$ and s 1314 continuing offences because they both potentially attach to a substantive offence provision in ch 7. Relevantly, s 4K of the Crimes Act applies to all federal offences unless a contrary intention appears. Although on one view it may be thought that $\mathrm{s} 1314$ carves out the application of s $4 \mathrm{~K}$ to the Corporations Act, a closer review of the Corporations Act supports a different interpretation. Of the 299 offences in ch 7, only one offence - that being s $922 \mathrm{M}(3)$ - contains an express notation that 'section $4 \mathrm{~K}(2)$ does not apply'. The inclusion of this notation under s 922M(3) suggests that $\mathrm{s} 4 \mathrm{~K}(2)$ otherwise applies to all other offence provisions in ch 7 that contain a continuing obligation.

However, given how a 'continuing obligation' in s 4K is defined, s $4 \mathrm{~K}(2)$ only applies to the offence provisions in ch 7 that contain a time-specified obligation to do an act. In other words, s $4 \mathrm{~K}$ attaches to the offences in ch 7 containing a S 1314(1)-type continuing obligation, but not the offences containing a s 1314(2)type continuing obligation. This means that s 1314(1)- and (2)-type breaches are treated differently under the law, as a s 1314(1)-type continuing breach may constitute an offence under s 4K(2) and s 1314(3), whereas a s 1314(2)-type continuing breach can only constitute a continuing offence by virtue of $\mathrm{s} 1314(3)$. This is a difference that matters, given that a s $4 \mathrm{~K}(2)$ continuing offence arises immediately after the specified period lapses, with a separate continuing offence accruing for 'each day' the act remains undone; whereas a s 1314(3) continuing offence only arises after a conviction of the substantive offence provision has been secured (and even then, only one continuing offence arises for the entire period of the continuing breach). ${ }^{73}$

\footnotetext{
Ibid s 1314(5).

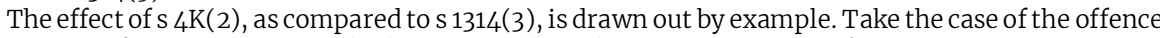
provided for by s $912 \mathrm{D}(1 \mathrm{~B})$, which requires a breach report to be lodged 'as soon as practicable and in any case within 10 business days'. If a regulated entity has failed to lodge a breach report after 20 days and there is a 10 day period of non-compliance, under s 1314(3) there is only a continuing offence after a conviction for the initial contravention has been secured. If a conviction is secured after day one of the breach period, ASIC could charge the defendant with a further offence for the
} 


\section{Different Types of Fault-Based Offences}

All criminal offences require proof of one or more physical elements. However, not all offences require proof of a fault element (such as intention, knowledge, recklessness or negligence). ${ }^{74}$ As a result, there are various different types of offences in ch 7, including full mens rea offences (this term is used to encapsulate both 'ordinary' and 'fault-based' offences - two terms used in the Corporations Act to denote offences with fault elements), which require proof of fault for every physical element of an offence, as well as strict and absolute liability offences (which dispose of the requirement to prove fault for all, or some, of the physical elements of an offence).

The starting position when interpreting the Corporations Act is that all criminal offences are presumed to be full mens rea offences. Therefore, when no fault elements are included in the drafting of an offence, so-called 'default' fault elements are imported by virtue of s 5.6 of the Criminal Code. ${ }^{75}$ The default elements are: 'intention', if the physical element of the offence consists of only conduct; or 'recklessness', if the physical element of the offence consists of a circumstance or a result.

The operation of s 5.6 must be kept front of mind when analysing the offence provisions in ch 7. As evident from the review undertaken above, many of the offence provisions in ch 7 are drafted as broad statutory norms without fault elements expressly drafted into the provision. This is demonstrated by general offences, ${ }^{76}$ but also formula-two specific offences, with so-called 'ordinary' and 'fault-based' offences sitting on multiple tracks alongside identically worded civil liability and strict liability provisions. ${ }^{77}$

However, the presumption that an offence in the Corporations Act is fault based can be rebutted in two ways: if the provision establishing the offence contains no penalty, or if the offence is otherwise expressly specified to be an offence without fault elements (such that it is a strict liability or absolute liability offence).

nine-day period for which the obligation continues and the act remains undone. In contrast, under $\mathrm{s} 4 \mathrm{~K}(2)$, because there is no requirement that a primary conviction be obtained first, and each day of non-compliance constitutes a separate offence, ASIC can charge the defendant with 11 separate offences immediately (a charge for the primary offence and 10 further 'continuing' offences, one for each day).

$74 \quad$ See Criminal Code s 5.1

75 In Gore v ASIC (2017) 249 FCR 167, 221 [245], Rares J held, in relation to s 727(1) of the Corporations Act, that '[n]o physical or fault elements are specified ... and, so, s 5.6 of the Code creates the relevant default fault elements for each of the physical elements constituting an offence against s 727(1)'.

76 The Parliament's intent, when introducing the general offences was that 'in most instances the default fault elements specified in the Criminal Code ... will be implied into offences': see EM Financial Reform Bill (n 50) 48 [6.123]; see also, Longo (n 36) 16; and see above Part II(A)(2).

77 See above Part II(A)(3)(b) 
Section $1311 \mathrm{~F}$ deals with the first exception. As noted above, ${ }^{78} \mathrm{~S} 1311 \mathrm{~F}$ makes an offence provision that does not specify a penalty a 'strict liability offence' with a penalty of ' 20 penalty units'. Notably, there is no work for s $1311 \mathrm{~F}$ to do in ch 7 as there is a penalty specified for all of the offence provisions. However, examples of $\mathrm{s} 1311 \mathrm{~F}$ strict liability offences may arise in the future when/if amendments are made to ch 7 .

The second exception is when the Corporations Act provides that the fault elements that would otherwise be supplied through s 5.6 of the Criminal Code do not apply. There are two examples of this in ch 7: (1) strict liability offences; and (2) absolute liability offences. Accordingly, s 5.6 of the Criminal Code must be read in context with s 6.1 (strict liability) and s 6.2 (absolute liability) of the Criminal Code. ${ }^{79}$ The Criminal Code treats strict liability and absolute liability alike as instances of liability 'without fault'. That is, neither strict nor absolute liability offences require proof of intention, knowledge, recklessness or negligence. ${ }^{80}$ The only difference between the two is that the defence of 'mistake of fact' under s 9.2 of the Criminal Code is available for a strict liability offence but not an absolute liability offence. ${ }^{81}$ There is only one absolute liability offence in ch 7, that being section 908BA(1). ${ }^{82}$ In contrast, strict liability offences are commonplace, there being 35 strict liability offences in total. ${ }^{83}$

There are two types of strict liability offences in ch 7, 'full' strict liability offences (there being no fault element for any of the physical elements of the offence) and 'partial' strict liability offences (there being no fault element for specified physical elements of the offence). ${ }^{84}$ Of the 35 strict liability offences in ch 7,19 are full strict liability offences. ${ }^{85}$

\section{Seriousness of the Criminal Offences in Chapter 7}

Yet another way to analyse the offence provisions in ch 7 is by reference to their 'seriousness'. More often than not, the seriousness of an offence provision is measured by the maximum penalty that attaches to it. From the perspective of a corporate actor, the penalty sets the risk or 'cost' of not complying with the law.

\footnotetext{
See above Part II(A)(4).

Stephen Odgers, Principle of Federal Criminal Law (Thomson Reuters, 2015) 80 [5.6.100]. Criminal Code Practitioners Guide (n 58) 7.

Criminal Code (n 22) ss 6.1, 6.2.

The offence in s 908BA(1) arises when an administrative of a significant financial benchmark does not hold a benchmark administrator licence.

Corporations Act (n 1) ss 791A(1), 820A(1), 912F(1), 916F(3), 952C(1), 952E(6), 952G(2), 952G(4), 952G(6), 952I(1), 952I(2), 952I(3), 952I(4), 952J(1), 985D(1), 985J(1), 985J(2), 985J(4), 989CA(4), 993B(1), 993C(1), 993D(3), 1020AI(3), 1021C(1), 1021FA(2), 1021FB(3), 1021FB(6), 1021H(1), $1021 \mathrm{M}(1), 1021 \mathrm{NA}(3), 1021 \mathrm{NB}(3), 1021 \mathrm{O}(1), 1041 \mathrm{E}(1), 1054 \mathrm{~A}(3), 1058(1)$.

Criminal Code (n 22) s 6.1.

Corporations Act (n 1) ss 912F(1), 952C(1), 985D(1), 985J(1), 985J(2), 985J(4), 989CA(4), 993B(1), 993C(1), 993D(3), 1020AI(3), 1021C(1), 1021M(1), 1021O(1), 1058(1).
} 
The penalty also expresses the legislators' view of the level of public condemnation and opprobrium attaching to the proscribed conduct. However, in addition to being the measurement or consequence of non-compliance with the law, the maximum penalty also shapes how a prosecution proceeds once an accused is charged. For example, the size of the maximum penalty determines whether an offence is classified as either a summary or an indictable offence (which informs in which court the offence is prosecuted) and whether an offence is subject to a limitation period. This section first analyses the maximum penalties applicable to the offence provisions in ch 7 before considering where the offences sit in the summary/indictable categorisation and whether they are subject to a limitation period.

\section{Size of Penalty Attaching}

The size of the maximum penalty attaching to the 299 offence provisions in ch 7 varies significantly. For an individual, a prison sentence attaches to 222 , or 73 per cent, of the offence provisions in ch $7,{ }^{86}$ with the maximum term varying from six months to 15 years. ${ }^{87} \mathrm{~A}$ fine, measured by a specified number of penalty units,

Ibid ss 791A(1), 791B, 792B(1), 792B(2), 792B(3), 792B(4), 792B(5), 792C(1), 792D(1), 792E, $792 \mathrm{~F}(1), 792 \mathrm{~F}(3), 792 \mathrm{G}(1), 792 \mathrm{G}(2), 793 \mathrm{D}(3), 794 \mathrm{~B}(3), 798 \mathrm{C}(3), 798 \mathrm{C}(6), 798 \mathrm{D}(4), 798 \mathrm{DA}(4)$, $820 \mathrm{~A}(1), 820 \mathrm{~B}, 821 \mathrm{~B}(1), 821 \mathrm{~B}(2), 821 \mathrm{~B}(3), 821 \mathrm{~B}(4), 821 \mathrm{BA}(1), 821 \mathrm{C}(1), 821 \mathrm{C}(3), 821 \mathrm{D}, 821 \mathrm{E}(1)$, $821 \mathrm{E}(2), 821 \mathrm{E}(3), 822 \mathrm{D}(3), 823 \mathrm{~B}(3), 850 \mathrm{C}, 851 \mathrm{D}(8), 852 \mathrm{~B}(2), 853 \mathrm{~F}(1), 853 \mathrm{~F}(2), 854 \mathrm{~A}(4), 892 \mathrm{~B}(1)$, $892 \mathrm{~B}(3), 892 \mathrm{H}(1), 892 \mathrm{H}(2), 892 \mathrm{H}(3), 892 \mathrm{H}(6), 892 \mathrm{H}(7), 892 \mathrm{~K}(2), 907 \mathrm{~A}, 911 \mathrm{~A}(1), 911 \mathrm{~B}(1), 911 \mathrm{C}$, $912 \mathrm{C}(3), 912 \mathrm{D}(1 \mathrm{~B}), 912 \mathrm{D}(2), 912 \mathrm{E}(1), 916 \mathrm{~A}(3 \mathrm{~A}), 916 \mathrm{~B}(2 \mathrm{~A}), 916 \mathrm{~B}(5 \mathrm{~A}), 916 \mathrm{C}(3), 916 \mathrm{D}(2 \mathrm{~A}), 916 \mathrm{~F}(1)$, 916F(1A), 916G(2), 916G(3), 920C(3), 942B(8), 942C(8), 942E, 943F, 949A(2), 949A(5), 949B(2), $949 \mathrm{~B}(4), 952 \mathrm{C}(3), 952 \mathrm{D}(1), 952 \mathrm{D}(2), 952 \mathrm{E}(6), 952 \mathrm{~F}(2), 952 \mathrm{~F}(3), 952 \mathrm{~F}(4), 952 \mathrm{G}(2), 952 \mathrm{G}(4)$, 952G(6), 952H(2), 952K, 952L(1), 952L(2), 952L(3), 952M, 982C(1), 982C(2), 982D, 983C, 985K(1), 988A(1), 989B(1), 989B(2), 989B(3), 989CA(3), 990B(1), 990B(2), 990B(6), 990D(1), 990D(2), 990F(a), 990I(3), 990K(1), 991B(2), 991E(1), 991E(3), 991F(1), 991F(2), 991F(3), 992A(1), 992A(3), 992AA(1), 993B(3), 993C(3), 993D(2), 1012DA(9), 1012DAA(10), 1012H(2), $1013 \mathrm{I}(4), 1013 \mathrm{IA}(5), 1013 \mathrm{~K}(1), 1013 \mathrm{~K}(2), 1015 \mathrm{~B}(1), 1015 \mathrm{D}(2), 1015 \mathrm{D}(3), 1015 \mathrm{D}(4), 1015 \mathrm{E}(1), 1016 \mathrm{~A}(2)$, $1016 \mathrm{~A}(3), 1016 \mathrm{~B}(1), 1016 \mathrm{C}, 1016 \mathrm{D}(1), 1016 \mathrm{D}(2)(\mathrm{d}), 1016 \mathrm{E}(2), 1017 \mathrm{~B}(1), 1017 \mathrm{C}(2), 1017 \mathrm{C}(2 \mathrm{~A}), 1017 \mathrm{C}(3)$, $1017 \mathrm{C}(3 \mathrm{~A}), 1017 \mathrm{C}(5), 1017 \mathrm{D}(1), 1017 \mathrm{E}(3), 1017 \mathrm{E}(4), 1017 \mathrm{~F}(2), 1017 \mathrm{G}(1), 1018 \mathrm{~A}(1), 1018 \mathrm{~A}(2), 1018 \mathrm{~B}(1)$, $1020 \mathrm{~A}(4), 1020 \mathrm{AB}(3), 1020 \mathrm{AC}(2), 1020 \mathrm{AD}(2), 1020 \mathrm{AE}, 1020 \mathrm{AI}(5), 1020 \mathrm{AI}(7), 1020 \mathrm{AJ}, 1020 \mathrm{BAA}(1)$, $1020 \mathrm{E}(8), 1020 \mathrm{E}(9), 1021 \mathrm{C}(3), 1021 \mathrm{D}(1), 1021 \mathrm{D}(2), 1021 \mathrm{E}(5), 1021 \mathrm{~F}(1), 1021 \mathrm{FA}(1), 1021 \mathrm{FA}(2)$, $1021 \mathrm{FB}(1), 1021 \mathrm{FB}(2), 1021 \mathrm{FB}(3), 1021 \mathrm{FB}(6), 1021 \mathrm{G}(2), 1021 \mathrm{I}(1), 1021 \mathrm{~J}(1), 1021 \mathrm{~J}(2), 1021 \mathrm{~J}(3)$, $1021 \mathrm{~K}(1), 1021 \mathrm{~L}(1), 1021 \mathrm{~L}(2), 1021 \mathrm{M}(3), 1021 \mathrm{~N}, 1021 \mathrm{NA}(1), 1021 \mathrm{NA}(2), 1021 \mathrm{NA}(3), 1021 \mathrm{NB}(1)$, $1021 \mathrm{NB}(2), 1021 \mathrm{NB}(3), 1021 \mathrm{O}(3), 1021 \mathrm{P}(1), 1021 \mathrm{P}(2), 1021 \mathrm{P}(4), 1023 \mathrm{P}(1), 1023 \mathrm{P}(2), 1023 \mathrm{P}(4), 1041 \mathrm{~A}$, $1041 \mathrm{~B}(1), 1041 \mathrm{C}(1), 1041 \mathrm{D}, 1041 \mathrm{E}(1), 1041 \mathrm{~F}(1), 1041 \mathrm{G}, 1043 \mathrm{~A}(1), 1043 \mathrm{~A}(2), 1101 \mathrm{~B}(10), 1101 \mathrm{C}(1)$, $1101 \mathrm{C}(2), 1101 \mathrm{C}(3), 1101 \mathrm{E}(1), 1101 \mathrm{~F}(1), 1101 \mathrm{~F}(1 \mathrm{~A}), 1101 \mathrm{G}, 908 \mathrm{BA}(1), 908 \mathrm{BB}, 908 \mathrm{DA}(3), 908 \mathrm{DB}(3)$, $984 \mathrm{~B}(1)$ (although if the offence only relates to a contravention of the requirements in 984B(1)(a) the penalty is a fine only), $1020 \mathrm{~B}(2)$ (although a first offence under $\mathrm{s} 1020 \mathrm{~B}(2)$ is punishable by a fine only).

87 Ibid. There are 15 offences carrying a maximum penalty of 15 years imprisonment: ss 952D(1), $952 \mathrm{D}(2), 952 \mathrm{~F}(2), 952 \mathrm{~F}(3), 952 \mathrm{~F}(4), 952 \mathrm{~L}(1), 993 \mathrm{~B}(3), 1021 \mathrm{D}(1), 1021 \mathrm{D}(2), 1041 \mathrm{~A}, 1031 \mathrm{~B}(1)$, $1041 \mathrm{C}(1), 1041 \mathrm{D}, 1041 \mathrm{E}(1), 1041 \mathrm{~F}(1), 1041 \mathrm{G}, 1043 \mathrm{~A}(1), 1043 \mathrm{~A}(2), 908 \mathrm{DA}(3), 908 \mathrm{DB}(3)$. 
attaches to the remaining 77 offences, ${ }^{88}$ with the maximum penalty varying from 20 penalty units (or $\$ 4,440$ ) to 1,000 penalty units (or $\$ 222,000$ ). ${ }^{89}$

There are only 14 offence provisions in ch 7 that expressly specify the penalty that applies to a body corporate. ${ }^{90}$ For the remaining 285 offences, in order to determine the maximum penalty applying to a body corporate, the penalty that applies to an individual must be converted using the 'body corporate formula' set out in s 1311C of the Corporations Act. Section 1311C sets out three different formulas by which the maximum penalty is calculated for a body corporate.

First, if the maximum penalty specified for an offence is 10 years imprisonment or more, then the maximum penalty is the greater of: (1) $\$ 9,990,000$ (45,000 penalty units); (2) three times the value of the benefit derived or the detriment avoided by the contravention; or (3) 10 per cent of the annual turnover of the corporation for the 12 month period at the end of the month in which the company committed or began committing the offence. ${ }^{91}$ Relevantly, ch 7 contains 20 offence provisions which fall into this category. ${ }^{92}$

Second, if the maximum penalty specified for an offence is a term of imprisonment of less than 10 years, the maximum penalty for a body corporate is calculated in two steps. ${ }^{93}$ The first step converts the term of imprisonment into the fine that would apply to an individual, using the 'individual fine formula' in $\mathrm{s} 1311 \mathrm{~B}$. This multiplies the term of imprisonment expressed in months by 10 (the result expressed as penalty units). 94 The second step multiplies the fine that applies to an individual by 10. Accordingly, a specified penalty of one year imprisonment applicable to an individual converts to a maximum penalty of $\$ 266,400$ for a body corporate, as follows:

Step 1: Calculating individual fine

- 12 months (prison term in months) x $10=120$ penalty units

Step 2: Calculating body corporate fine

88 Ibid ss $792 \mathrm{~F}(2), 792 \mathrm{I}, 904 \mathrm{~B}(1), 904 \mathrm{~B}(5), 904 \mathrm{C}(1), 904 \mathrm{C}(3), 904 \mathrm{D}(2), 904 \mathrm{E}, 904 \mathrm{H}(3), 912 \mathrm{~F}(1)$, 916F(3), 922M(3), 946AA(4), 946B(3A), 946B(9), 952C(1), 952I(1), 952I(2), 952I(3), 952I(4), 952J(1), 985D(1), 985J(1), 985J(2), 985J(4), 989CA(4), 993B(1), 993C(1), 993D(3), 1017DA(3), $1020 \mathrm{AI}(3), 1021 \mathrm{C}(1), 1021 \mathrm{H}(1), 1021 \mathrm{M}(1), 1021 \mathrm{O}(1), 1021 \mathrm{P}(3), 1021 \mathrm{P}(5), 1021 \mathrm{P}(6), 1070 \mathrm{~B}(1), 1070 \mathrm{C}(1)$, $1070 \mathrm{D}(3), 1071 \mathrm{~B}(2), 1071 \mathrm{E}, 1072 \mathrm{E}(11), 1072 \mathrm{H}(1), 1072 \mathrm{H}(3), 1072 \mathrm{H}(4), 1072 \mathrm{H}(5), 1072 \mathrm{H}(6)$, 908BQ(1), 908BR(2), 908BS, 908BV(4), 921L(7), 921M(1), 921M(2), 921M(3), 921P(2), 922HC(3), 1054A(3), 1054B(4), 1054BA(4), 1058(1), 794D(3), 794E(2), 823D(5), 823E(3), 904G(5), 904K(4), $905 \mathrm{~A}(2), 923 \mathrm{~A}(1), 923 \mathrm{~B}(1), 923 \mathrm{C}(1), 923 \mathrm{C}(2), 1052 \mathrm{~B}(3), 1052 \mathrm{BA}(4), 1052 \mathrm{C}(6)$. As of 1 July 2020, the value of a penalty unit is \$222. See, Crimes Act 1914 (Cth) s 4AA ('Crimes Act'). Corporations Act (n 1) ss 794D(3), 794E(2), 823D(5), 823E(3), 904G(5), 904K(4), 905A(2), 923A(1), 923B(1), 923C(1), 923C(2), 1052B(3), 1053BA(4) and 1052C(6).

Ibid s $1311 \mathrm{C}(3)$.

92 Ibid ss $952 \mathrm{D}(1), 952 \mathrm{D}(2), 952 \mathrm{~F}(2), 952 \mathrm{~F}(3), 952 \mathrm{~F}(4), 952 \mathrm{~L}(1), 993 \mathrm{~B}(3), 1021 \mathrm{D}(1), 1021 \mathrm{D}(2), 1041 \mathrm{~A}$, $1031 \mathrm{~B}(1), 1031 \mathrm{C}(1), 1041 \mathrm{D}, 1041 \mathrm{E}(1), 1041 \mathrm{~F}(1), 1041 \mathrm{G}, 1043 \mathrm{~A}(1), 1043 \mathrm{~A}(2), 908 \mathrm{DA}(3), 908 \mathrm{DB}(3)$.

Ibid s $1311 \mathrm{C}(2)$.

94 Crimes Act (n 89) s 4AA. 
- 120 penalty units (individual fine expressed in penalty units) x $10=1,200$ penalty units

- 1,200 penalty units $x \$ 222.00=\$ 266,400$

There are 200 offences in ch 7 that contain prison terms of less than 10 years and require the above two-step calculation to determine the maximum penalty that applies to a body corporate. ${ }^{95}$ The maximum penalty specified for these 200 offences ranges between six months and five years for an individual, which converts to fines ranging between 600 penalty units $(\$ 133,200)$ and 6,000 penalty units $(\$ 1,332,000)$ for a body corporate.

Third, if the maximum penalty specified for an offence is a fine, the penalty applicable to a body corporate is 'the fine specified multiplied by 10 '. ${ }^{96}$ Relevantly, the 10-times multiplier takes effect on the 'specified fine', 97 which is expressed in penalty units, not the fine expressed as a monetary amount. Although a technical distinction, this has practical ramifications. For example, whether the prosecution of an offence is subject to a limitation period when brought against a body corporate turns on the size of the 'fine' as measured in penalty units, not as a monetary amount (see discussion below at Part II(C)(3)).

There are 63 offences in ch 7 that specify a fine as the penalty attaching and require the above calculation. ${ }^{98}$ The maximum penalties attaching to these 63

Corporations Act (n 1) ss 791A(1), 791B, 792B(1), 792B(2), 792B(3), 792B(4), 792B(5), 792C(1), 792D(1), 792E, 792F(1), 792F(3), 792G(1), 792G(2), 793D(3), 794B(3), 798C(3), 798C(6), 798D(4), 798DA(4), 820A(1), 820B, 821B(1), 821B(2), 821B(3), 821B(4), 821BA(1), 821C(1), 821C(3), 821D, $821 \mathrm{E}(1), 821 \mathrm{E}(2), 821 \mathrm{E}(3), 822 \mathrm{D}(3), 823 \mathrm{~B}(3), 850 \mathrm{C}, 851 \mathrm{D}(8), 852 \mathrm{~B}(2), 853 \mathrm{~F}(1), 853 \mathrm{~F}(2), 854 \mathrm{~A}(4)$, $892 \mathrm{~B}(1), 892 \mathrm{~B}(3), 892 \mathrm{H}(1), 892 \mathrm{H}(2), 892 \mathrm{H}(3), 892 \mathrm{H}(6), 892 \mathrm{H}(7), 892 \mathrm{~K}(2), 907 \mathrm{~A}, 911 \mathrm{~A}(1), 911 \mathrm{~B}(1)$, 911C, 912C(3), 912D(1B), 912D(2), 912E(1), 916A(3A), 916B(2A), 916B(5A), 916C(3), 916D(2A), 916F(1), 916F(1A), 916G(2), 916G(3), 942B(8), 942C(8), 942E, 943F, 949A(2), 949A(5), 949B(2), $949 \mathrm{~B}(4), 952 \mathrm{C}(3), 952 \mathrm{E}(6), 952 \mathrm{G}(2), 952 \mathrm{G}(4), 952 \mathrm{G}(6), 952 \mathrm{H}(2), 952 \mathrm{~K}, 952 \mathrm{~L}(2), 952 \mathrm{~L}(3), 952 \mathrm{M}$, 982C(1), 982C(2), 982D, 983C, 985K(1), 988A(1), 989B(1), 989B(2), 989B(3), 989CA(3), 990B(1), 990B(2), 990B(6), 990D(1), 990D(2), 990F(a), 990I(3), 990K(1), 991B(2), 991E(1), 991E(3), $991 \mathrm{~F}(1), \quad 991 \mathrm{~F}(2), \quad 991 \mathrm{~F}(3), \quad 992 \mathrm{~A}(1), 992 \mathrm{~A}(3), 992 \mathrm{AA}(1), \quad 993 \mathrm{C}(3), 993 \mathrm{D}(2), \quad 1012 \mathrm{DA}(9)$, 1012DAA(10), 1012H(2), 1013I(4), 1013IA(5), 1013K(1), 1013K(2), 1015B(1), 1015D(2), 1015D(3), $1015 \mathrm{D}(4), 1015 \mathrm{E}(1), 1016 \mathrm{~A}(2), 1016 \mathrm{~A}(3), 1016 \mathrm{~B}(1), 1016 \mathrm{C}, 1016 \mathrm{D}(1), 1016 \mathrm{D}(2)(\mathrm{d}), 1016 \mathrm{E}(2), 1017 \mathrm{~B}(1)$, $1017 \mathrm{C}(2), 1017 \mathrm{C}(2 \mathrm{~A}), 1017 \mathrm{C}(3), 1017 \mathrm{C}(3 \mathrm{~A}), 1017 \mathrm{C}(5), 1017 \mathrm{D}(1), 1017 \mathrm{E}(3), 1017 \mathrm{E}(4), 1017 \mathrm{~F}(2)$, $1017 \mathrm{G}(1), 1018 \mathrm{~A}(1), 1018 \mathrm{~A}(2), 1018 \mathrm{~B}(1), 1020 \mathrm{~A}(4), 1020 \mathrm{AB}(3), 1020 \mathrm{AC}(2), 1020 \mathrm{AD}(2), 1020 \mathrm{AE}$, 1020AI(5), 1020AI(7), 1020AJ, 1020B(2), 1020BAA(1), 1020E(8), 1020E(9), 1021C(3), 1021E(5), $1021 \mathrm{~F}(1), 1021 \mathrm{FA}(1), 1021 \mathrm{FA}(2), 1021 \mathrm{FB}(1), 1021 \mathrm{FB}(2), 1021 \mathrm{FB}(3), 1021 \mathrm{FB}(6), 1021 \mathrm{G}(2), 1021 \mathrm{I}(1)$, $1021 \mathrm{~J}(1), 1021 \mathrm{~J}(2), 1021 \mathrm{~J}(3), 1021 \mathrm{~K}(1), 1021 \mathrm{~L}(1), 1021 \mathrm{~L}(2), 1021 \mathrm{M}(3), 1021 \mathrm{~N}, 1021 \mathrm{NA}(1), 1021 \mathrm{NA}(2)$, $1021 \mathrm{NA}(3), 1021 \mathrm{NB}(1), 1021 \mathrm{NB}(2), 1021 \mathrm{NB}(3), 1021 \mathrm{O}(3), 1021 \mathrm{P}(1), 1021 \mathrm{P}(2), 1021 \mathrm{P}(4), 1023 \mathrm{P}(1)$, $1023 \mathrm{P}(2), 1023 \mathrm{P}(4), 1101 \mathrm{~B}(10), 1101 \mathrm{C}(1), 1101 \mathrm{C}(2), 1101 \mathrm{C}(3), 1101 \mathrm{E}(1), 1101 \mathrm{~F}(1), 1101 \mathrm{~F}(1 \mathrm{~A}), 1101 \mathrm{G}$, 908BA(1), 908BB.

Ibid s $1311 \mathrm{C}(1)(\mathrm{a})$.

Emphasis added.

Ibid ss 792F(2), 792I, 904B(1), 904B(5), 904C(1), 904C(3), 904D(2), 904E, 904H(3), 912F(1), 916F(3), 922M(3), 946AA(4), 946B(3A), 946B(9), 952C(1), 952I(1), 952I(2), 952I(3), 952I(4), 952J(1), 984B(1), 985D(1), 985J(1), 985J(2), 985J(4), 989CA(4), 993B(1), 993C(1), 993D(3), $1017 \mathrm{DA}(3), 1020 \mathrm{AI}(3), 1021 \mathrm{C}(1), 1021 \mathrm{H}(1), 1021 \mathrm{M}(1), 1021 \mathrm{O}(1), 1021 \mathrm{P}(3), 1021 \mathrm{P}(5), 1021 \mathrm{P}(6)$, 
offences for an individual range between 20 penalty units $(\$ 4,440)$ and 100 penalty units $(\$ 22,200)$. Once these fines are adjusted by the formula in s $1311 \mathrm{C}$ (ie, multiplied by 10), the maximum penalties that apply to a body corporate for these offences ranges between 200 penalty units $(\$ 44,400)$ and 1,000 penalty units $(\$ 222,000)$.

\section{Summary or Indictable}

The size of the maximum penalty attaching to an offence provision determines whether an offence is categorised as a summary or an indictable offence. The Crimes Act defines a summary offence as being any federal offence punishable by fewer than 12 months imprisonment, 99 and an indictable offence as being any federal offence punishment by at least 12 months imprisonment. ${ }^{100}$

The summary/indictable categorisation is significant as it impacts how the prosecution of an offence will progress. Summary offences are commenced and tried in a state local court (or magistrates' court) and are heard by a magistrate alone. In contrast, indictable offences are 'committed' for trial in a local court but tried in a superior court before a judge and jury. ${ }^{101}$ Indeed, all federal indictable offences must proceed before a jury, as s 80 of the Australian Constitution forbids the waiver of a trial by jury in preference of trial by a judge alone, as may occur in state jurisdictions. ${ }^{102}$

The superior court to which a federal indictable matter is transferred once 'committed' turns on the offence. The presumptive position is that the prosecution of indictable offences in ch 7 are to be committed for trial in a state district court (or county court). ${ }^{103}$ White-collar offences are only transferred to a state supreme court on application by one of the parties. This will occur if the case involves high-stakes or is particularly complex, a common example being insider

1070B(1), 1070C(1), 1070D(3), 1071B(2), 1071E, 1072E(11), 1072H(1), 1072H(3), 1072H(4), 1072H(5), $1072 \mathrm{H}(6), 908 \mathrm{BQ}(1), 908 \mathrm{BR}(2), 908 \mathrm{BS}, 908 \mathrm{BV}(4), 921 \mathrm{~L}(7), 921 \mathrm{M}(1), 921 \mathrm{M}(2), 921 \mathrm{M}(3), 921 \mathrm{P}(2)$, $922 \mathrm{HC}(3), 1054 \mathrm{~A}(3), 1054 \mathrm{~B}(4), 1054 \mathrm{BA}(4), 1058(1)$. Note, there are only 63 offence provisions and not 77 , as 14 of the 77 offence provisions specify a separate 'fine' for a body corporate and individual and therefore do not require conversion under s 1311C. See above (n 90) and accompanying text.

99 Crimes Act (n 89) s $4 \mathrm{H}$.

100 Ibid s 4G.

101 Ian Bolster and Stephen Speirs, 'Corporate and Criminal Law: Stepping Through the Stages of a Corporate Criminal Prosecution' (2019) 61 Law Society of NSW Journal 69. Note, the committal process for indictable offences differs from state to state. See ALRC Final Report (n 14) 46 [1.71].

102 Alqudsi $v$ The Queen (2016) 258 CLR 203.

103 Bolster and Speirs (n 101) 69. 
trading cases (but presumably this principle would apply to most indictable offences in ch 7, given the complexity of the offence provisions). ${ }^{104}$

The vast majority of the 299 offence provisions in ch 7 are indictable offences. When committed by individuals, 211 (or 70 per cent) of the offences are indictable and the remaining 88 are summary offences. For corporate defendants, 210 of the offences are indictable offences and 89 are summary offences. This unequal division of summary and indictable offences, which turns on whether the defendant is an individual or body corporate, arises by dint of s 905A(2).

Section $905 \mathrm{~A}(2)$ is one of the 14 offence provisions in ch 7 that specifies a separate penalty for a body corporate and an individual, namely, two years imprisonment for an individual, which renders it an indictable offence (the penalty being more than 12 months imprisonment), and 5,000 penalty units for a body corporate, a summary offence (the penalty being less than 12 months imprisonment). ${ }^{105}$ This concept of specifying a separate penalty for a body corporate and individual was introduced as part of the Strengthening Penalties Bill reforms in February 2019. Previously, all of the offences in ch 7 specified a single penalty (being the penalty that applied to an individual), with the penalty applying to a body corporate ascertained by converting the individual penalty pursuant to the former s 1312 (which itself was repealed and replaced by s 1311C). Of these 14 offences, s $905 \mathrm{~A}(2)$ is the only offence that creates a summary or indictable categorisation problem because it is the only offence that specifies a penalty of imprisonment for an individual on the one hand, and a fine for a body corporate on the other. In contrast, the maximum penalty specified for each of the other 13 offences (for both an individual and body corporate) is expressed as a 'fine', ensuring that those offences are summary offences against both the individual and the body corporate.

It is apparent that the intention behind specifying a separate penalty for an individual and body corporate was to ensure that a body corporate defendant pay a larger fine than otherwise would apply if the penalty applicable to an individual were converted using the s $1311 \mathrm{C}$ formula. Taking s $905 \mathrm{~A}(2)$ as the example, the specified maximum penalty against a body corporate of 5,000 penalty units equates to a monetary fine of $\$ 1,110,000$, which is more than double the size of the financial penalty that would apply if the maximum penalty of two years imprisonment that applies to an individual is converted using s 1311C.

See, eg, Rv Curtis (No 3) [2016] NSWSC 866. Note, the Federal Government has recently announced that it intends to establish an indictable jurisdiction for serious corporate crimes in the Federal Court of Australia. See Attorney-General (Cth) and Minister for Industrial Relations, '\$35 Million to Extend the Federal Court's Jurisdiction to Corporate Crime' (Media Release, 22 March 2019). This jurisdiction appears set to replicate the Federal Court's jurisdiction in relation to serious cartel offences. At the time of writing, this reform has not yet been instituted, although it is difficult to imagine it not applying to ch 7 offences.

105 Crimes Act (n 89 s $4 \mathrm{H}$ and $4 \mathrm{G}$.. 
Understanding the objective of specifying separate penalties for a body corporate and individual for the same offence as being aimed at increasing the penalty that a body corporate pays, serves only to further highlight the perversity of the outcome when the offence in $\mathrm{s} 905 \mathrm{~A}$ is translated into the summary/indictable categorisation. That is, by specifying a penalty for a body corporate that is greater than that which would apply if the individual prison term were converted using the formula in s 1311C, the offence, paradoxically, goes from being a serious indictable offence that is tried in a superior court before a judge and jury when enforced against an individual, to a less serious summary offence tried in a local court before a magistrate when enforced against a body corporate.

\section{Limitation Periods}

The size of the maximum penalty is also relevant to determining whether an offence is subject to a statutory limitation period. The limitation period in which proceedings must be commenced with respect to breaches of the offence provisions in the Corporation Act is set by s 15B of the Crimes Act and s 1316 of the Corporations Act.

Pursuant to s $15 \mathrm{~B}$ of the Crimes Act, the prosecution of an offence must be commenced within one year of the alleged conduct occurring if the penalty attaching to the offence does not exceed six months imprisonment (if the defendant is an individual), ${ }^{106}$ or 150 penalty units (if the defendant is a body corporate). ${ }^{107}$ Section 1316 of the Corporations Act extends the one year limitation period specified by $\mathrm{S} 15 \mathrm{~B}$ of the Crimes Act to five years (or longer with the Minister's consent). ${ }^{108}$ Accordingly, s 15B of the Crimes Act and s 1316 of the Corporations Act combine to impose a limitation period of five years for all offences in ch 7 that carry a penalty of fewer than six months imprisonment (for an individual) or less than 150 penalty units (for a body corporate).

Of the 299 offence provisions in ch 7, 88 offence provisions contain a penalty of six months (or fewer) imprisonment and have a limitation period of five years when applied against an individual. Against a body corporate, however, none of the offence provisions have a penalty of less than 150 penalty units, meaning that the prosecution is free to commence proceedings against a body corporate at any time. This is because (as set out above in Part II(C)(1)), the smallest penalty specified for an offence provision in ch 7 - being 20 penalty units - converts to 200 penalty units for a body corporate once the formula in s 1311C is applied. Thus, notwithstanding the express intent of $\mathrm{s} 15 \mathrm{~B}(1 \mathrm{~A})(\mathrm{a})$, to ensure that limitation periods apply for less serious offences for body corporates, s 1311C has the effect

\footnotetext{
Crimes Act (n 89) s 15B(1)(a).

Ibid s 15B(1A)(a).

Attorney General v Oates (1999) 198 CLR 162.
} 
of rendering s $15 \mathrm{~B}(1 \mathrm{~A})(\mathrm{a})$ nugatory, disqualifying a body corporate from the protections afforded to a natural person accused of the same offence.

\section{iII A Simplification Project}

The criminal regime in ch 7 is extremely complex. To find a criminal offence, one needs to weave through a web of complicated and interlocking provisions - both within the Corporations Act and across other federal statutes. This complexity is compounded by the fact that the exercise must be repeated no fewer than 299 times to completely analyse the regime - an effort that is hardly conducive to the promotion of compliance and observance of the law. From the review undertaken in Part II, it is evident that the legislature has neither charted nor followed a conventional route. As a result, urgent reform is required to forge clear and consistent paths through the criminal regime in ch 7.

The complexity in ch 7 is a topic that has attracted considerable attention recently. Commissioner Hayne made various observations to this effect during the Royal Commission. In the Interim Report, the Corporations Act was described as containing a 'blizzard of provisions' and as being 'labyrinthine and overly detailed' ${ }^{109}$ In the Final Report, Commissioner Hayne opined that the volume, complexity and deconstructed nature of much of the regime made compliance difficult. ${ }^{110}$ Similarly, in 2019, the ALRC observed, following its examination of 25 separate federal statutes, that the complexity of criminal offences in federal law is a problem 'exemplified in the Corporations Act' ${ }^{111}$ And in September 2020, the Attorney-General commissioned the ALRC to conduct a review into Australia's financial services law in order to 'identify ways to make it more adaptive, efficient and navigable for consumers and regulated entities'. ${ }^{112}$

Having regard to these observations, and noting the drafting issues identified in Part II, a project to simplify the criminal regime in ch 7 ought to be undertaken. The aim of such a project would be straightforward: to make clear when conduct regulated by the Corporations Act constitutes an offence and may attract criminal consequences. The importance of these objectives cannot be overstated. The availability and accessibility of the laws by which a regulated entity or individual is expected to abide is fundamental to achieving a fair, equal and effective criminal justice regime. Speaking extra-curially in November 2018, Chief Justice Allsop remarked that:

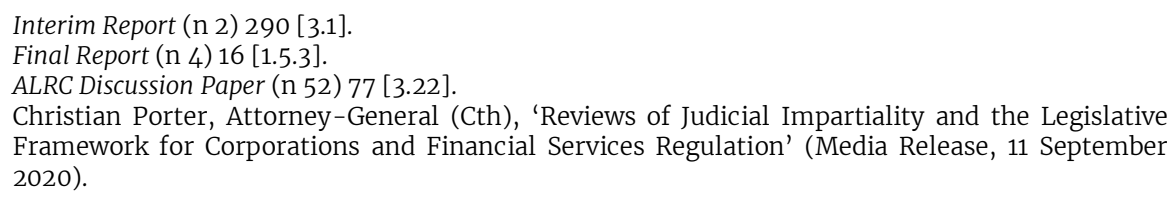

Christian Porter, Attorney-General (Cth), 'Reviews of Judicial Impartiality and the Legislative Framework for Corporations and Financial Services Regulation' (Media Release, 11 September 2020). 
The need to define, with clarity, the limits and content of criminal liability is clear, indeed, perhaps self-evident. The law as to criminal responsibility should be as certain as possible, with as little place for value judgment as is reasonably possible. This is so even though the criminal law is regulating human relationships and experience from where the substantive content of the rules of liability must be derived. If the rules of criminal responsibility do not conform to, and are not expressed by reference to, and in language conformable with, the relationally human and the experiential, they will lose community consent and respect. ${ }^{113}$

A simplification project is also likely to result in making the criminal regime more user-friendly for ASIC and the CDPP. As Commissioner Hayne observed in the Interim Report of the Royal Commission, simplicity assists the prosecution as well, because 'the more complicated the law, the easier it is to lose sight of them'. ${ }^{114}$

Despite being straightforward in its objective, legislative simplification is often difficult to achieve. ${ }^{115}$ Australia's corporate law and regulations have been the subject of a number of 'simplification' reforms since the 1980 s with varying degrees of success. ${ }^{116}$ However, none of these prior attempts at simplification have focused solely on the criminal regime in ch 7, as is proposed here. ${ }^{117}$ Given the size and complexity of the criminal regime in ch 7, any attempt at simplification would be a significant undertaking, demanding considerable resources. The ALRC's current review into Australia's financial services regime may yet provide that opportunity. Although the terms of reference do not specifically call into focus the criminal regime in ch 7 , the regime clearly falls within the broader ambit of the review, and the ALRC has been granted considerable resources and more than three years to conduct its review.

The remainder of this Part sets out reform proposals aimed at simplifying the criminal regime in ch 7. There are three main objectives to this project: (1) to ensure the offence provisions in ch 7 are clearly drafted, consistent, and easy to 'find'; (2) to reconcile the interaction between the offence provisions in ch 7 and other federal statutes, especially the Crimes Act;118 and (3) to consider whether

Chief Justice James Allsop, 'The Rule of Law is not a Law of Rules' (Speech, Annual Quayside Oration, 1 November 2018) 9.

Interim Report (n 2) 290 [3.1].

Final Report (n 4) 16 [1.5.3]

For example, the First Corporate Law Simplification Act 1995 (Cth) was passed to amend the corporations legislation in force at the time. A subsequent, Second Corporate Law Simplification Bill was introduced to the Commonwealth Parliament in 1996, but never passed. It was largely incorporated into the Company Law Review Act 1998 (Cth). In March 1997, the 'Corporate Law Economic Reform Programme' (CLERP) was introduced to replace the simplification taskforce.

See ASIC Taskforce (n 52) 24 [51]. The ASIC Enforcement Review Taskforce did propose some amendments to criminal provisions and the penalties attaching. However, these proposals were piecemeal and did not consider the criminal regime as a whole.

The reform proposals will not focus on the intersection between the Corporations Act and the Criminal Code, including the operation of ss 769A and 769B. This is because these provisions have recently been examined by the ALRC in its review of Australia's corporate criminal responsibility regime (see generally, ALRC Final Report (n 14)), and also because it falls outside the scope of this article. 
there is scope for removing offence provisions in ch 7 so as to address concerns of over-criminalisation. ${ }^{119}$

\section{A Objective 1 - Offence Provisions to be Clear, Consistent and Easy to Find}

Much of the complexity of the criminal regime in ch 7 is due to the difficulty in finding offence provisions. This difficulty results from there being a lack of consistency in how the offence provisions have been drafted. As canvassed in Part II of this article, ch 7 comprises general offences, and formula-one and formula-two specific offences. In addition, each of these offences sits on a distinct 'enforcement track' crafted to fit the drafting style of each offence. Unfortunately, there is no 'quick fix' to this problem, and a comprehensive redrafting of the relevant provisions with simplification and consistency as the ultimate objectives is necessary in order to make each the offence provisions more easily locatable. There are three main reforms required to achieve this objective.

\section{Make All Offence Provisions Formula-Two Specific Offences}

The obvious solution to this problem is to adopt a single drafting style for all offence provisions in ch 7. Given the number of offence provisions, consolidation to a single style is no small task. As the vast majority of the offence provisions in ch 7 (205 of 299) are general offences, conforming all of the offence provisions to general offences would require amendment to the least number of provisions. This approach is problematic for at least two reasons.

First, general offences are not 'clearly' drafted and thus fail to meet the stated objectives of the proposed simplification project. As discussed in Part II, general offences are drafted as broad 'statutory norms' and are not offences per se. Due to the difficulty in identifying general offences on their face, the legislature has inserted notations referring to s 1311(1); however, this has resulted in further inconsistencies as notations have been omitted (perhaps by mistake) for some of the general offences. ${ }^{120}$

Second, general offences are not as dynamic as formula-two specific offences, which allow for multiple-track provisions, such as criminal/criminal/civil tracks (providing the regulator with a choice between a 'fault-based offence', 'strict liability offence', or a civil penalty provision, to enforce the prohibited conduct). General offences have only been drafted to facilitate dual tracks (being a choice between a criminal offence - either a mens

Some proposals to address over-criminalisation were made by the ALRC as part of its review in Australia's corporate criminal responsibility regime. See ALRC Final Report (n 14) 167-215. 
rea or strict liability offence, but not both - and a civil penalty provision). To maintain the flexibility provided by the multiple tracks on which formula-two specific offences sit, the general offence provisions would need to be amended to provide for multiple alternatives.

In Part II, this article described formula-one specific offences as being the most clearly drafted offence provisions in ch 7. At first blush, then, that formula might appear to be the most obvious candidate for the simplification project. However, while formula-one specific offences are notable in reflecting clear and express drafting, they fail when it comes to ensuring the offences in ch 7 are easy to find. As explained in Part $\operatorname{II}(\mathrm{A})(1)(\mathrm{a})$, because the penalty attaching to a formula-one specific offence is listed in a provision of the Corporations Act and not sch 3, the only way to identify a formula-one specific offence is to locate the provision in the body of the Corporations Act. Without some impetus to search, one could be forgiven (though not by any court) for not realising that an offence existed.

Given these drawbacks, this article advocates for all offences in ch 7 to be drafted as formula-two specific offences. Formula-two specific offences do away with the problematic features of general and formula-one specific offences, while retaining the best features of both. A formula-two specific offence is clear and express on its face (like a formula-one specific offence), but easy to identify because the penalty is listed in sch 3 (like a general offence). Thus, formula-two specific offences achieve the objectives of the simplification project proposed in this article, as they are clearly drafted and easy to find. Formula-two specific offences are also preferred as they provide regulators with the broadest suite of enforcement options to the extent that they can sit on 'multiple tracks'. ${ }^{121}$

It should be observed that, notwithstanding their description as formulatwo 'specific' offences, those offences are not inconsistent with the recommendations of the Royal Commission, or the stated preference by the ALRC in its 'preliminary analysis' as part of its financial services review, which cautions against an overly prescriptive approach to financial services regulation. ${ }^{122}$ As discussed above in Part II(A), despite their namesake, 'specific offences' in ch 7 can also be (and often are) broadly drafted so-called 'omnibus' provisions. In this sense, the name 'specific offence' in the vernacular of the Corporations Act (as defined by Bird and Gilligan) is reflective of the form of the offence only.

In order to make all of the offences in ch 7 formula-two specific offences, the following amendments are required:

1. Section $1311 \mathrm{E}(1)(\mathrm{b})$ should be repealed, so that penalties can only be specified in sch 3.

${ }_{121}$ See above Part II(A)(3)(b).

${ }_{122}$ See ALRC Preliminary Analysis (n 20). See also Final Report (n 4) 492, recommendations 7.3 and 7.4. 
2. The 18 formula-one specific offences in ch 7 should be redrafted as formula-two specific offences, with the penalty specified in sch 3 . The two provisions sitting on the 'scheme' track (being ss 908DA(3) and 908DB(3)) should be redrafted as criminal/civil mutiple-track provisions.

3. The 205 general offences in ch 7 should be re-drafted as formula-two specific offences. The 13 general offences which sit on dual-track provisions should be re-drafted as criminal/civil mutiple-track provisions.

4. Section $1311 \mathrm{~F}$, which creates default strict liability offences for offence provisions with no specified penalty, should be repealed. The idea that an offence can arise by 'default' when no penalty is specified is inconsistent with the objectives of the simplification project that all offences in ch 7 be clearly drafted and easily identifiable by being located in sch 3.

\section{Amendments to Formula-Two Specific Offences}

Although this article argues that formula-two specific offences best achieve the objectives of the simplification project, one amendment to formula-two specific offences is required. This amendment relates to the co-existence of 'ordinary offences' and 'fault-based offences'. As explored in Part II(A)(1)(b), apart from the fact that an 'ordinary offence' sits on a criminal/criminal multiple-track provision (ie, it is the mens rea offence alternative to a strict liability offence) and a 'fault-based offence' sits on a criminal/civil multiple-track provision (ie, it is the mens rea offence alternative to a civil penalty), these offences seem to be identical. The co-existence of these two terms (neither of which is defined in the Corporations Act) for the same type of offence is unnecessary, and appears to have confused the drafters themselves (as is demonstrated by s 989CA).123

To address this confusion, this article proposes that only one term be used, and that the preferred term be defined in the dictionary in s 9 of the Corporations Act.

\section{Inserting Notations Under Offence Provisions to which Section 1314(3) Attaches}

Consistently with the objective of making offences easier to identify, a notation under all substantive offence provisions that contain a continuing obligation and enliven s 1314(3) ought to be inserted. The notation will serve a similar function to the notations that currently attach to most general offence provisions (ie,

123 See above Part II(A)(3)(b)(iv). 
providing notice when s 1311(1) applies). Drawing attention to continuing offences is consistent with their objective: to incentivise compliance with a provision (so that the act is done) after an initial contravention has been committed.

\section{B Objective $2-$ Reconciling the Offence Provisions with the Crimes Act}

The Crimes Act contains matters of general application to all federal offences including those in ch 7 of the Corporations Act. The review in Part II identified three sources of tension, where the criminal regime in ch 7 is either inconsistent, or otherwise in direct conflict with, matters specified in the Crimes Act. These three situations are: (1) the way the Corporations Act criminalises continuing obligations as compared to the approach taken in the Crimes Act; (2) the categorisation of the offence provisions in ch 7 into summary and indictable offences; and (3) whether the offence provisions in ch 7 are subject to limitation periods.

This Part proposes reforms to address these three situations so that the criminal regime in ch 7 sits in harmony with the Crimes Act.

\section{Continuing Offences}

The intersection between s $4 \mathrm{~K}$ of the Crimes Act and s 1314 of the Corporations Act is one of the real mysteries of the criminal regime in the Corporations Act. As outlined above in Part II(B)(1)(b), a continuing obligation caught by s 1314(1) is also caught by s $4 \mathrm{~K}(2)$ of the Crimes Act; however, the continuing obligation regulated by s $1314(2)$ is not. The result of this inconsistency is that a failure to do an act caught by s 1314(1) can also be charged under s $4 \mathrm{~K}(2)$, whereas a failure to do an act regulated by s 1314(2) cannot.

This discrepancy is considerable when noting the differences between s 1314(3) and s 4K(2). Section 1314(3) requires that a conviction be secured first before a continuing offence can arise and, even then, the continuing offence is charged as a single 'course of conduct' offence. In contrast, s $4 \mathrm{~K}(2)$ does not depend on an initial conviction being secured and creates a further offence for each day that the continuing obligation remains undone.

The simplest way to resolve this inconsistency would be to either expressly carve out s $4 \mathrm{~K}$ from applying to ch 7 of the Corporations Act or, alternatively, repeal s 1314 and rely on S $4 \mathrm{~K}$ in its place. Neither approach, however, is satisfactory. It is clear that the legislature intended to insert s 1314 in order to expand the types of acts which continue. This is evidenced by the inclusion of the continuing obligation in s 1314(2), which regulates acts that are not time-specified and which is not regulated by s $4 \mathrm{~K}$ of the Crimes Act. The issue with s 1314 as it currently operates, however, is that an offence under s 1314(3) is not enlivened until after an initial conviction of the substantive offence provision 
has been secured. Delaying liability for a continuing breach until after an initial conviction for a breach of the substantive offence provision has been secured removes any incentive for a person or regulated entity to comply with the act (even if the act continues under s 1314(1)) until a conviction has, or is about to be, secured, (which can take a number of years). This is clearly inconsistent with the policy basis of a continuing offence.

Accordingly, while s 1314 must remain in order for both s 1314(1) and (2) continuing obligations to be regulated, it requires amendment so that an offence for a continued breach of a s 1314(1)-type obligation arises as soon as the relevant period lapses. This can be achieved by amending s 1314(3) to reflect the language of $s 4 \mathrm{~K}(2)$, so that it applies as follows:

Where a refusal or failure to comply with a requirement in subsection (1) and (2) is an offence against a law of the Commonwealth, a person commits an offence in respect of each day during which the person refuses or fails to comply with that requirement, including the day of a conviction for any such offence or any later day. ${ }^{124}$

Further, in order to make express that only s 1314 applies to the offences in ch 7, a notation should be inserted which states expressly that $\mathrm{s} 4 \mathrm{~K}$ of the Crimes Act has no application.

\section{Summary/Indictable Categorisation}

As set out in Part II(C)(2) above, s 905A(2) is either a summary or an indictable offence, depending on whether the offence is prosecuted against a body corporate or an individual. This outcome is clearly unintended, especially when it is noted that the separate penalty imposed for a body corporate (5,000 penalty units) is larger than the fine that would apply to a body corporate if the maximum fine applicable to an individual (two years imprisonment) were converted using the formula in s 1311C.

There are two ways that this inconsistency can be addressed. The first approach is to make the same maximum penalty apply to a body corporate as applies to an individual and rely on s $1311 \mathrm{C}$ to convert the individual penalty to a body corporate penalty. This approach, however, would be in conflict with the clear legislative intent that the financial penalty applicable to a body corporate for the conduct regulated by s $905 \mathrm{~A}(2)$ be more substantial than a fine that otherwise

If this amendment to s 1314 were to be adopted, the legislature may be minded to incorporate subss (3) and (4) of s $4 \mathrm{~K}$ of the Crimes Act as well, which allow the prosecution to join charges and empowers the Court to impose an aggregate sentence. 
applies to a body corporate after a two year prison term has been converted using S 1311C..$^{25}$

The second, and perhaps, preferable approach is to keep separate penalties for a body corporate and individual, but make it express that the offence against a body corporate (even if specified as a fine) is an indictable offence. Although departures from the summary/indictable distinction as defined by ss $4 \mathrm{G}$ and $4 \mathrm{H}$ of the Crimes Act are rare, the Commonwealth Attorney-General Department's Guide to Framing Federal Offences expressly recognises that departures should be made 'where there is a clear and cogent reason for such a departure', including 'where an offence is punishable by a large fine or where prosecution of an offence will involve the proof of complex issues'. ${ }^{226}$ Section $905 \mathrm{~A}(2)$ fits both of these criteria. The amendment required is straightforward and could be achieved by inserting a notation which specifies that 'an offence against section $905 \mathrm{~A}(2)$ when enforced against a body corporate is an indictable offence'. Similar notations have been inserted in the Competition and Consumer Act 2010 (Cth) with respect to the cartel offences at ss $45 \mathrm{AF}$ and $45 \mathrm{AG}$.

\section{Limitation Periods}

As set out in Part II(C)(3) above, the interaction between s 15B(1A)(a) of the Crimes Act, which expressly provides that the initiation of criminal proceedings with respect to less serious federal offences against a body corporate should be subject to time limits, has been rendered nugatory by the effect of s $1311 \mathrm{C}$ of the Corporations Act, which calculates the penalty that applies to a body corporate, by multiplying the maximum penalty which applies to an individual by 10 .

It would appear that this result is unintended. Supporting this inference, when introducing s 1311C, the Federal Government made no reference to limitation periods and was focused solely on increasing the monetary penalty applicable to a body corporate. In other words, the objective driving s $1311 \mathrm{C}$ was to increase the monetary or financial penalty that a corporation should pay, not removing protections that are afforded to a body corporate (which just so happen to be based on the size of the penalty attaching to the offence). If this reading is correct, s $1311 \mathrm{C}$ should be amended so that the maximum fine applicable to a body corporate may be calculated without interfering with the operation of $\mathrm{s}$

\footnotetext{
125 Section $1311 \mathrm{C}$ of the Corporations Act expressly recognises that the legislature may insert separate penalties for a body corporate and individual for the same offence thus mitigating the operation of s 1311C.

$126 \quad$ Framing Federal Offences (n 67) 43.
} 
$15 \mathrm{~B}(\mathrm{~A})(\mathrm{a}) .{ }^{127}$ Alternatively, if this reading is incorrect, and the intention was to remove $\mathrm{s} 15 \mathrm{~B}(\mathrm{~A})(\mathrm{a})$ from having any application to ch 7 offences, that intention should be made clear.

\section{Objective 3 - Addressing Concerns of Over-Criminalisation}

There are 299 offence provisions in ch 7. Although the number of offences in ch 7 is not a problem in itself, the offences should be reviewed to ensure that only appropriately serious conduct is criminalised. Offence provisions that do not regulate the most serious conduct - in particular, those that regulate what may be described as 'trivial' misconduct - should be repealed. An example is s 912F, which makes it a criminal offence when an AFSL holder fails to cite its licensee number on certain documents.

This proposal is consistent with a recent recommendation by the ALRC as part of its review of Australia's corporate criminal responsibility regime. The ALRC concluded that there is an over-proliferation of criminal offences in federal law and recommended that 'the majority of minor regulatory contraventions that are currently criminal offences ... become [civil penalty notice] provisions and be removed from the court system'. ${ }^{128}$ In relation to the regulation of body corporates in particular, the ALRC concluded that the criminal law should be reserved for only the most serious misconduct to preserve the condemnatory force of the criminal law. ${ }^{129}$

\section{CONCLUSION}

This article has undertaken the first detailed examination of the criminal regime in ch 7 of the Corporations Act. The aim was to identify and organise the criminal regime in ch 7 , in preparation for an expected uptick in the enforcement of the

This could be achieved by amending s 1311C, such that the 10-times multiplier is applied to the fine which applies to an individual (expressed as a monetary amount), as opposed to the penalty (expressed in penalty units). This is a technical distinction but is drawn out by the following example. Assuming a penalty of 20 penalty units applies to an individual, the effect of s $1311 \mathrm{C}$ as it currently operates calculates the penalty applicable to a body corporate in two steps as follows: (1): 20 penalty units $x 10=200$ penalty units; and (2) 200 penalty units x $\$ 222.00=\$ 44,400$. However, if the 10-times multiplier under $\mathrm{S} 1311 \mathrm{C}$ were to apply to the penalty applicable to an individual (expressed as a monetary amount rather than in penalty units), the two-step calculation would operate as follows: (1) 20 penalty units $x \$ 222.00=\$ 4,440$ (individual fine); and (2) $\$ 4,440 \times 10=$ $\$ 44,400$. The above calculation has the effect of multiplying the fine that applies to an individual (when expressed as a monetary amount) by 10, such that the fine is increased and the legislature's 'cost of doing business' concerns are addressed. However, the size of the penalty measured in penalty units remains 20 penalty units, meaning that the offence remains subject to a limitation period under $\mathrm{s} 15 \mathrm{~B}(1 \mathrm{~A})(\mathrm{a})$

${ }_{128}$ ALRC Discussion Paper (n 52) 91 [4.18].

129 Ibid $89[4.16]$. 
offence provisions in ch 7 following the Royal Commission. In the process of conducting this review, a number of issues and inconsistencies were identified primarily with respect to how the offence provisions have been drafted, but also with respect to how the offence provisions in ch 7 interact with provisions in the Crimes Act and Criminal Code.

In response to these issues, this article has advocated for the simplification of the criminal regime in ch 7, to make it clearer and easier to comply with. With the announcement in September 2020 that the ALRC is to conduct a detailed review into Australia's financial services laws and regulations, there is hope yet that the complexity of the criminal regime will be borne out and a movement to simplify it will gather momentum. 